\title{
Integrating Intercultural Competence development into the curriculum through Telecollaboration. A task sequence proposal for Higher Education
}

\section{Integrando la Competencia Intercultural en el curriculum mediante la Telecolaboración. Propuesta de una secuencia de tareas para la Educación Superior}

\author{
Luana Ferreira-Lopes \\ Universidad de Deusto, Bilbao, España \\ luana.ferreira@deusto.es \\ María José Bezanilla \\ Universidad de Deusto, Bilbao, España \\ marijose.bezanilla@deusto.es \\ Iciar Elexpuru \\ Universidad de Deusto, Bilbao, España \\ elexpuru@deusto.es
}

\begin{abstract}
Despite its demonstrated potential to enhance students' Intercultural Competence and other 21st century skills, telecollaboration still fails to be fully integrated into university courses. Literature shows that there is a need for developing sustainable instructional design models for this purpose. Hence, the main goal of this work is to propose a theory-informed task sequence to facilitate the integration of telecollaboration into university courses for the development of Intercultural Competence. Based on the typology of tasks from O'Dowd \& Ware (2009) and enriched with contributions from other authors, the task sequence: (1) facilitates the development of Intercultural Competence according to EMIC model and adds a new block to its composition in order to approach the specificities of virtual teamwork, (2) contains detailed instructions for each task, (3) provides guidelines on implementation, on the selection of technology and on the integration of tasks to the syllabi and (4) offers an assessment plan, accompanied by a list of learning evidences that are expected to be manifested by students per task. This sequence can serve as a reference for further adaptations to diverse contexts. It is currently being piloted in two telecollaborative projects and the results are expected to contribute to future improvements.
\end{abstract}

\section{Keywords}

Telecollaboration, Intercultural Competence, Higher Education, Blended Learning, Assessment

\section{Resumen}

Pese al potencial de la telecolaboración para desarrollar la Competencia Intercultural y otras competencias en la Educación Superior del siglo XXI, todavía no ha logrado consolidarse en la formación universitaria. De 
acuerdo con la literatura, es preciso desarrollar modelos instruccionales sostenibles para responder a esta necesidad. El principal objetivo de este trabajo es proponer una secuencia de tareas de telecolaboración para el desarrollo de la Competencia Intercultural en el curriculum universitario. A partir de la tipología de tareas propuesta por O'Dowd \& Ware (2009), enriquecida con el trabajo de otros autores, dicha secuencia: (1) facilita el desarrollo de la Competencia Intercultural según el modelo EMIC, adaptado al contexto del trabajo virtual, (2) ofrece instrucciones detalladas para cada tarea, (3) contiene orientaciones para la configuración de la telecolaboración, la tecnología a utilizar y la integración de las tareas en el curso y (4) sugiere un plan de evaluación con un listado de evidencias de aprendizaje que deben ser manifestadas por los alumnos en cada tarea. La propuesta podrá servir como referencia para futuras adaptaciones a diferentes contextos. La secuencia de tareas se está actualmente pilotando en dos proyectos de telecolaboración y se espera que los resultados puedan contribuir a su mejora.

\section{Palabras clave}

Telecolaboración, Competencia Intercultural, Educación Superior, Blended Learning, Evaluación

\section{Introduction}

In times of continuous advances in communication, technology, and transportation, the idea of culture as a stable, unique and defined notion to be passed on to future generations is becoming increasingly blurred. The use of computer-mediated communication tools like social networking environments, mobile devices and videoconferencing "constitutes a new way of understanding social participation and collaboration" (Guerin, Cigognini, \& Pettenati, 2010, p. 199) and, by connecting to virtual spaces, people have now the opportunity not only to learn from the interaction with several cultural backgrounds but also to promote cultural change (Raffaghelli \& Richieri, 2012). In the midst of this process, "global competencies are increasingly becoming a workplace requirement, regardless of the industry or geographic location" (Taras et al., 2013).

To address this issue, in the recent decades, Higher Education institutions have been gradually re-conceptualizing their eco-systems (European University Association, 2016) by adopting two main strategies. On the one hand, they are getting "equipped with cutting-edge information technologies and employed by lifelong learning experts, research workers and lecturers" (Teresevičienè, Volungevičienè, \& Daukšienè, 2011) while, on the other hand, they have been turning their attention to internationalisation as a means to remain competitive and to prepare students for a globalized world.

As one of the results of such efforts, we see the rise of virtual mobility as a tool that has been adopted by universities to combine both approaches in order to develop important $21^{\text {st }}$-century skills like Digital Literacy, Collaboration and Intercultural Competence. Among the different virtual mobility modalities available, this work focuses on the use of computer-mediated international collaboration for the development of Intercultural Competence, what has been called by practitioners just as Telecollaboration (Guth, Helm, \& O’Dowd, 2012; O’Dowd \& Ware, 2009), as Online Intercultural Exchange 
(OIE) (O’Dowd, 2007; O'Dowd \& Lewis, 2016) or as Collaborative Online International Learning (COIL) (Guth \& Rubin, 2015) and which refers to "the engagement of groups of students in online intercultural interaction and collaboration with partner classes from other cultural contexts or geographical locations under the guidance of educators and/or expert facilitators" (O'Dowd \& Lewis, 2016, p.3).

The majority of telecollaborative activities for the development of Intercultural Competence in universities are carried out in a blended-learning set-up, meaning that such practices are seen as a part of classroom activities in which interactions based on physical presence are used alternatively with technology-based resources (Guth et al., 2012). Telecollaborative projects have demonstrated to develop learner autonomy (Fuchs, Hauck, \& Müller-Hartmann, 2012; Lee, 2011), language skills (Wu, Marek, \& Chen, 2013; Yang, 2013) and different dimensions of Intercultural Competence (Lai \& Li, 2011; Liaw, 2006; Müller-Hartmann, 2000; O’Dowd, 2007; Schenker, 2012; Vallés, 2017; Vinagre, 2014) and research shows a high level of positive attitude of teachers and students towards this learning approach (Helm, 2015).

Notwithstanding, despite its potential to enhance students' Intercultural Competence and to become a complementary strategy to physical mobility in the internationalisation of Higher Education, telecollaboration for intercultural development still fails to be fully integrated into university courses and "the idea of introducing telecollaboration as a tool in subject areas outside of foreign language education appears to be quite new" (O'Dowd, 2016, p. 288). As Helm (2015) concludes from a survey held with 142 universities covering 23 different European countries about the practices and challenges in telecollaboration:

there is scope for more "pre-packaged" telecollaboration projects with a more or less fixed curriculum, duration, assessment tools, and even facilitators for specific target groups and contexts...having a well-established syllabus and project is one way of relieving educators of some of the time burden that the organization of telecollaboration projects imposes, and would also facilitate the integration into curricula and recognition with credits. Research needs to be carried out on the development, piloting, and evaluation of sustainable models of telecollaboration which will allow more students and educators to engage in this practice. (p. 213)

Zapata-Ros (2014) also highlights the need for an instructional design for interculturality, one that articulates theories and models with practice and research. The author states that "we have advanced very little in this direction" (p. 12) and suggests that more has to be researched on how to organize teaching in order to meet the needs of what he calls 'new interculturality', referring to a cross-border education, which, differently from the classical interculturality, considers the continuous cultural exchange between individual-groups-spaces present in contemporary societies.

Having this said, this work attempts to provide Higher Education teachers with a task sequence to support the design of telecollaborative programmes for the development of students' Intercultural Competence. The material aims at being an aid for building international online collaborations and can be beneficial for Higher Education teachers and lectures who believe that their students' learning can be enhanced by the contact with students from other cultures; to Higher Education Programme Administrators 
(directors and coordinators) who wish to implement innovative learning approaches in their courses; and to Higher Education institutions who want to foster 'Internationalisation at Home' strategies across their Faculties and Departments.

The task sequence presented herein was developed based on a literature review which sought to find an Intercultural Competence model to be used as a theoretical reference and the best instructional design methods to be adopted for the development of such competence through telecollaborative programmes. As a result, the sequence (a) proposes the use of Erasmus Mundus Intercultural Competence (EMIC) model, followed by a list of specific learning outcomes and adapted to virtual teamwork, (b) offers detailed instructions for each task, (c) gives guidelines on pre-implementation setup, the adoption of technology to be used and the integration of online tasks into the coursework and also (d) suggests a plan to assess students' Intercultural Competence development during the telecollaboration. The main findings of such review as well as the developed sequence are presented in the next sections.

\section{Defining Intercultural Competence}

For decades, different authors have tried to define Intercultural Competence and hence literature offers a multitude of Intercultural Competence models and frameworks (Arasaratnan-Smith, 2017; Spitzberg \& Changnon, 2009). From such universe, our study adopts the EMIC Intercultural Competence model (2015b) as the main reference for a conceptual definition of Intercultural Competence. Such model is based on the intercultural challenges faced by international students in Higher Education during mobility and is a result of a combination of theoretical research and the analysis of interviews held with a sample of Erasmus Mundus administrators, students, and alumni (Lukic, Solari, \& Yarosh, n.d.).

The model (Figure 1) is composed of four building blocks (Knowledge, Awareness, Attitudes, and Skills), two supporting competences (Critical Reflection and Emotional Intelligence), one meta-capacity (Developing Intercultural Competence), three broad spheres of application (academic, professional and private) and three sub-competences (Intercultural Teamwork, Intercultural Conflict Management and Intercultural Relationship Building). 


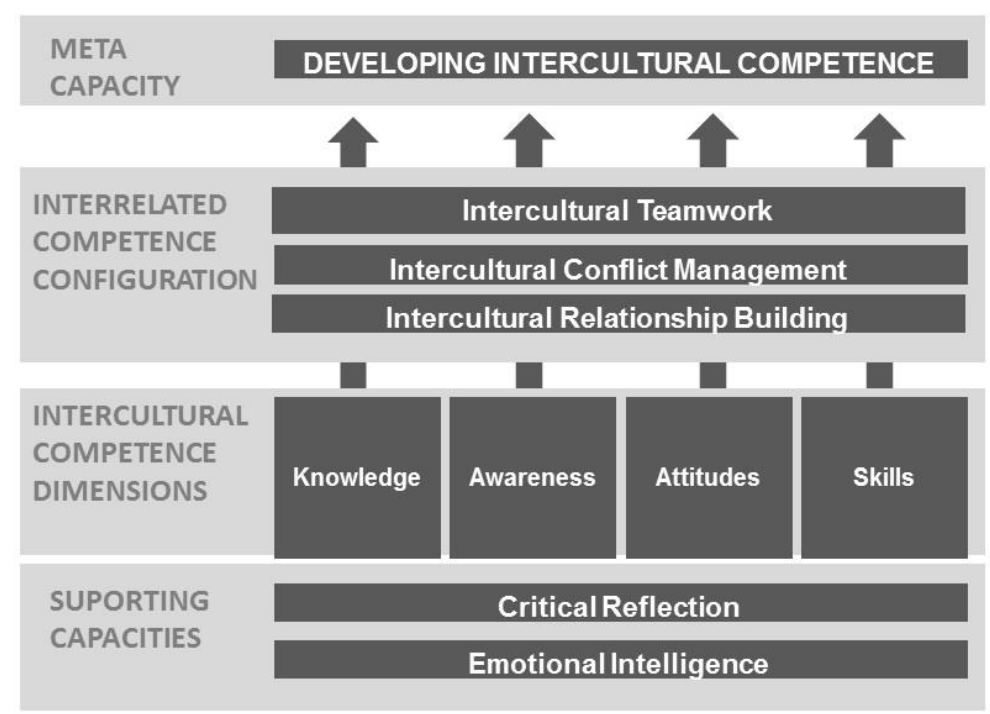

Figure 1. The EMIC Model. Adapted from EMIC (2015b, p. 13). Available at: www.emic-project.org/emic-toolkit. Adapted with permission

To begin with EMIC's supporting capacities, in the model, critical reflection is seen as the ability to overcome judgmental thinking and to deal with stereotypes. As for Emotional Intelligence, EMIC relates it to empathy, managing one's own emotions and being able to deal with uncertainty. Concerning the building blocks from the model, knowledge comprises culture-specific knowledge and conceptual knowledge of Intercultural Competence. Awareness is divided in three types: intercultural awareness (awareness of differences between cultures), cultural self-awareness and awareness of specific cases when culture is at play. Attitudes approach acceptance of differences, openness, non-judgmental attitude, tolerance, flexibility, cooperative mindset, valuing diversity and respect. Skills involve being able to communicate, intercultural mediation, verbalizing cultural expectations and norms, the ability to notice cultural differences, the ability to speak about cultural practices that might feel disturbing, the ability to detect misunderstandings, the ability to detect how one's behavior is perceived, acting on culture-specific knowledge and on intercultural awareness, the ability to adjust one's behavior to intercultural contexts, developing/adopting new behaviors, dealing with people with lower Intercultural Competence and the ability to shift between different cultural environments.

The three intercultural competence configurations proposed by EMIC (Intercultural Teamwork, Intercultural Conflict Management and Intercultural Relationship Building) comprise the "competences that were distinguished as particularly relevant for Intercultural Competence in practice" (EMIC, 2015b, p. 19) and represent the arena on which students are expected to apply the other elements constituting the model. Related to this, the model acknowledges that the competence can be applied in three broad spheres: in private/social lives, in studies/academia and in the workplace (EMIC, 2015b).

Moving on to the development of Intercultural Competence, EMIC's meta capacity "Developing Intercultural Competence" approaches specifically this aspect and is divided in meta-knowledge (which involves knowing what Intercultural Competence is

Integrating Intercultural Competence development into the curriculum through Telecollaboration. A task sequence proposal for Higher Education. Luana Ferreira-Lopes, Maria José Bezanilla and Iciar Elexpuru. 
and how it can be developed) meta-awareness (which relates to one's awareness of one's own identity and personal learning needs), meta-skills (which require one's abilities to identify and build cultural knowledge, to monitor one's own Intercultural Competence development and to manage one's intercultural identity) and meta-attitudes (which are the attitudes needed to develop one's Intercultural Competence, such as orientation towards a lifelong Intercultural Competence development, proactive attitude towards developing Intercultural Competence, appreciating the full potential of the competence and embracing learning from different sources of cultural diversity) (EMIC, 2015b).

It is important to notice that EMIC's multidimensional approach to Intercultural Competence is consonant with the Intercultural Competence models which served as the theoretical basis for its construction (EMIC, 2015a). Fantini (2005), for instance, defends that Intercultural Competence is a manifold concept composed of a variety of individual traits and characteristics, three areas or domains, four dimensions knowledge, attitudes, skills and awareness, proficiency in the host language and varying levels of attainment throughout a longitudinal and developmental process. In its turn, the Deardoff study (2006) brought up 22 essential Intercultural Competence elements, which addressed individual's personal attributes (like curiosity, general openness, and respect for other cultures), adaptive traits, cultural knowledge and cognitive skills. In the same direction, the Cultural Intelligence construct (CQ) (Ang et al., 2007) is composed of four different dimensions (CQ-Strategy, CQ-Knowledge, CQ-Motivation and CQ-Behaviour) and Byram (1997) proposes that Intercultural Competence is composed of five 'savoirs': knowledge (savoirs), skills (savoir comprendre and savoir apprendre/faire) and attitudes (savoir être).

Besides its composition, the developmental view of Intercultural Competence adopted by EMIC was also influenced by other research works (EMIC, 2015a). In the DMIS model, Bennett (1993) defends that people can be more or less sensitive to cultural differences in a process that moves from an ethnocentric position, in which one sees his own culture as central to reality, to an ethnorelativist position, in which one acknowledges that his cultural affiliations are only one of the possible ways to interpret reality. From Deardorff's (2006) work, EMIC drew the idea that there are degrees of Intercultural Competence and that its development occurs from the inside (internal outcomes, like flexibility, adaptability and empathy) to the outside (external outcomes, related to the appropriate and effective behavior in an intercultural situation). From King \& Baxter Magolda (2005), EMIC adopts the concept that achieving "intercultural maturity" is a lifelong process, having this complemented the by idea that one should develop the ability to carry one's own growth (Williams, 2009). Furthermore, in the Deep Culture Model of intercultural learning (Shaules, 2007), EMIC model found an Intercultural Competence dimension that lacked in the other works reviewed and which is related to the idea that intercultural learners need to "better understand and embrace their own cultural learning process, so they can deal with further adaptive demands" (EMIC, 2015a, p. 3).

Finally, the fact that EMIC Intercultural Competence model integrates other wellknown Intercultural Competence frameworks from the literature makes it especially suitable for the guide to be proposed in this paper. In fact, three Intercultural 
Competence models included in EMIC's theoretical approach - Byram's five saviors model, the Intercultural Maturity model and Bennett's DMIS model - are among the frameworks which are mostly used in telecollaboration (Lewis \& $\mathrm{O}^{\prime}$ Dowd, 2016). It is also important to say that EMIC Intercultural Competence model is part of a comprehensive toolkit proposed by EMIC research group to develop Intercultural Competence in Higher Education and which offers a set of Open Educational Resources (OER). The toolkit has been applied to four Erasmus Mundus courses - GIM (Global Innovation Management), MALLL (Master of Arts in Life Long Learning), EUROMIME (European Master in Media Engineering for Education) and WOP-P (Work, Organizations and Personnel Psychology) - and the "projects tested showed a clear impact on the participating sample" (Lukic, Solari, Martins, \& Yarosh, 2017, p. 6; EMIC, 2015c) in terms of Intercultural Competence development and perceptions. Despite having been designed for students participating in Erasmus Mundus master programmes, EMIC toolkit claims to be adaptable and "relevant for all students experiencing mobility internationally or home students studying in diverse settings, as well as in preparation for intercultural workplace experiences in their careers" (EMIC, 2015 b, p. 5). Therefore, for our work, from all the toolkit material, we chose to use the Intercultural Competence model and the related list of learning outcomes and to adapt such material to the context at hand, considering the added challenges that telecollaboration imposes to intercultural communication, as it is going to be explained in the presentation of the sequence.

\section{Instructional design in Telecollaboration}

In the last decades, together with technology, literature in the field of telecollaboration has significantly evolved. In such process, we see the emergence of diverse studies trying to identify the best methods to develop Intercultural Competence through telecollaboration and to assess its outcomes.

For structuring the task sequence presented in this paper, we opted to gravitate especially around the work of O'Dowd \& Ware (2009). By synthesizing the variety of tasks used by telecollaboration practitioners (based on a comprehensive review of over 40 studies found in the literature), the authors offered a good basis for decision-making in the design process of telecollaborative projects. In their review, they organized the tasks used in foreign language telecollaboration under three main categories: the first category is composed of 'information exchange tasks'. These tasks usually require little negotiation and basically consist of partners introducing themselves to each other by providing information about their biographies, interests, and cultures. The second type of tasks is 'comparison and analysis' and asks students to make a critical comparison of cultural products from both cultures (e.g. newspapers, magazines, books, etc.). The last category is 'collaborative tasks', which require students to go further in collaboration by requesting them to produce a joint product or conclusion together. In addition to identifying task types, the authors observed that task sequencing allowed educators to approach different learning objectives in a telecollaborative project and conducted students to gradually building relationship with collaborating peers.

Integrating Intercultural Competence development into the curriculum through Telecollaboration. A task sequence proposal for Higher Education. Luana Ferreira-Lopes, Maria José Bezanilla and Iciar Elexpuru. 
The task typology and sequencing identified by O'Dowd \& Ware have been used as reference for task design in different studies (for examples, see Hauck (2010) and Vinagre (2017)) and are in alignment with other important works about task design in telecollaboration. A review from Müller-Hartmann \& Schocker-von Ditfurth (2010) about the use of technology in task-based learning showed that learners prefer to be exposed to a variety of tasks and that structured environments which provide dialogic interaction lead to more critical thinking. Adopting a variety of tasks, having tasks which building up on each other and arranging tasks according to their complexity are also requirements found in the criteria for designing telecollaborative tasks developed by Kurek \& Müller-Hartmann (2017). Holding preliminary exchange of personal information has also demonstrated to have an essential role in enhancing students' positive attitude towards the collaboration (Schuetze, 2008) and in creating relationship building (Müller-Hartmann, 2000) and social presence (Liaw \& English, 2017). The sequence proposed herein also considers the importance of intensive reflection in the process of developing Intercultural Competence (Guth \& Rubin, 2015, MüllerHartmann, 2006) and, after completing each task, students are asked to reflect about what they have just done through questionnaires sent by the teachers or group discussions and reports.

In terms of integration of telecollaborative activities to the curriculum, the sequence proposed adopts a format labeled by Lewis \& O'Dowd (2016) as 'classroom integrated'. In this format, exchange tasks are clearly linked to the course syllabus, instead of just being considered a supplementary activity which is not officially incorporated into study programmes. A study by Nissen (2016) with six blendedlearning courses including telecollaboration also showed that virtual exchange was the backbone (lead mode) of all the cases analysed and that the role of the face-to-face sessions in all the six courses was to prepare students for the Online Intercultural Exchange activities.

For pre-implementation setup, we have considered the work of Guth \& Rubin (2015), who suggest that collaborating teachers, in a first moment, should share details of the academic culture in their institutions (such as the number of hours per week, grading scheme, expectations in relation to class attendance, participation in class, in-class and out-of-class amount of work) and advise teachers to align objectives and avoid overloading students in order to give them enough time to engage in communication with their peers. In a reflection about the evolution of their telecollaborative project over twelve years, Sadler \& Dooly (2016) also highlight that, despite of the physical distance, it is essential that teachers work closely during collaboration and fully share "the planning of the calendar, activities, interaction, output, assessment, and implementation...thereby giving the students two referents in each class (a local and an international teacher)" (p. 412).

In relation to tools, though asynchronous communication prevails in telecollaboration (Helm, 2015), we rely on a review from Çiftçi (2016), which showed that most of the studies about Intercultural Learning through Computer-Based Digital Technologies used more than one digital tool to foster students' intercultural interaction, and on 
Vinagre (2014), who suggests combining asynchronous and synchronous tools respectively. We also considered the work of Guth \& Thomas (2010), who suggest that, when picking tools to work with, teachers should verify terms related to users' access and permissions and choose tools that have demonstrated to be stable through the years and that has a large user base.

For the evaluation and assessment of Intercultural Competence in Telecollaboration, in consonance with Vogt (2006) - who defends that a combination of instruments can reconstruct intercultural interactions in a more complete manner, allowing for a more precise assessment of attitudes by considering different variables - we suggest the use of different instruments for collecting quantitative and qualitative evaluation material. Based on O'Dowd (2010), who calls educators who implement Telecollaboration to identify clear descriptors of intercultural communicative skills and online literacies that can be developed through online exchanges, we have also developed a table with specific evidences expected to be delivered by students in relation to EMIC's learning outcomes in each task proposed.

Finally, with the decisions above mentioned, we intended to address some of the barriers to the integration of telecollaboration to Higher Education found in literature, namely, differences in institutional timetables, significant differences in teachers' aims and approach to exchange, different expectations on the part of students and/or educators and teacher and students' level of e-literacy and technical issues (Guth et al., 2012; Helm, 2015; O'Dowd, 2013a). For addressing the discourse tensions derived from intercultural online interactions (Kramsch \& Thorne, 2002; Ware \& Kramsch, 2005), and considering that discussing goals facilitates further group negotiation (Fuchs, 2006), one of the tasks of the developed sequence to be presented ahead proposes the elaboration of a group contract, which calls students to openly talk about communication genres, work style and expectations.

\section{The Proposed Task Sequence}

In the following lines, we propose a task sequence to support teachers in the integration of telecollaborative projects into the curriculum of university courses for the development of students' Intercultural Competence.

The sequence was designed to be interdisciplinary and customizable to courses in different Higher Education disciplines and cycles (undergraduate and graduate degrees). It was conceived to develop Intercultural Competence as a generic competence inside universities that adopt a competence-based Learning model and its learning programme can fit into course unities that aim at developing critical reflection/analysis, teamwork, interpersonal communication, intercultural/cross-cultural communication, digital skills, and other related competences. The material intends to guide instructors in the design of telecollaboration in Higher Education from pre-implementation settings to conclusion and, in order to do so, it suggests the adoption of an adapted version of EMIC's Intercultural Competence model, proposes specific instructions for each task, discusses issues related to the integration of telecollaborative tasks to the syllabus and to the

Integrating Intercultural Competence development into the curriculum through Telecollaboration. A task sequence proposal for Higher Education. Luana Ferreira-Lopes, Maria José Bezanilla and Iciar Elexpuru. 
selection of technology tools to be used and, in the end, puts forward a plan to assess the development of students' Intercultural Competence.

\section{Pre-implementation considerations}

At first place, considering some of the barriers to the integration of telecollaboration into university curriculum found in the literature (Guth et al., 2012; Helm, 2015; O'Dowd, 2013a) and the planning recommendations from Guth \& Rubin (2015) and Sadler \& Dooly (2016), we suggest collaborating teachers to hold a warm-up meeting (online or, whenever it is possible, face-to-face) to get to know each other and to prepare the ground for implementation. In this pre-implementation phase, teachers should align their expectations towards the collaboration and take important actions such as: (1) sharing /comparing courses syllabi (objectives and contents); (2) talking about expectations from students and from the online programme as a whole; (3) sharing academic calendars; (4) jointly adapting the task instructions proposed to the context of the specific collaboration; (5) deciding on the dates for each task; (6) deciding which of collaborating teachers will be in charge for sending task instructions to students on the dates defined or posting them on the online learning platform (if any is adopted); (7) deciding how collaborating teachers will monitor students participation in the tasks; (8) deciding the technology tools to be used for each task, (9) deciding how collaborating teachers will evaluate students' delivered material in each task (for example, selecting which of the suggested learning outcomes will be considered for each task and deciding which of the suggested evaluation instruments will be applied), (10) exchanging the list of students' names, and (11) creating groups composed of students from the different participating universities. For the sequence proposed, we suggest that, before the beginning of the project, teachers create groups with around five members in total and watch for a balance between students from different localities and cultures represented

Regarding scheduling, we advise that the programme proposed in the guide is implemented in courses that last at least one semester. Such length should allow an even distribution of tasks along the months and enough time for completing activities. When planning a schedule for the tasks, exam periods should be protected in order to ensure students' availability for completing the proposed activities. Another consideration to have in mind when preparing for the implementation of the learning programme relates to the choice of the language for the virtual exchange. Given that language development is not among the primary objectives of the sequence (though it is likely to happen as a side result of the collaboration) and that literature showed that the different levels of language fluency among students' in telecollaborative groups might lead to failed communication (O'Dowd \& Ritter, 2006), we recommend that the project is carried out in a 'lengua franca' which can be spoken by all members of the working groups.

\section{Intercultural Competence Model}

As said before, this task sequence adopts the EMIC Intercultural Competence model (2015) for the definition of Intercultural Competence and its elements. Since literature highlights the importance of defining Intercultural Competence according to the context

Integrating Intercultural Competence development into the curriculum through Telecollaboration. A task sequence proposal for Higher Education. Luana Ferreira-Lopes, Maria José Bezanilla and Iciar Elexpuru. 
to which it will be applied (Fantini, 2009), we propose adaptations to the model chosen so that the virtual dimension added by telecollaboration to intercultural teamwork can be addressed. As a result, we see the inclusion of a new Intercultural Competence Configuration to the original model (Intercultural Virtual Teamwork), as seen in Figure 2.

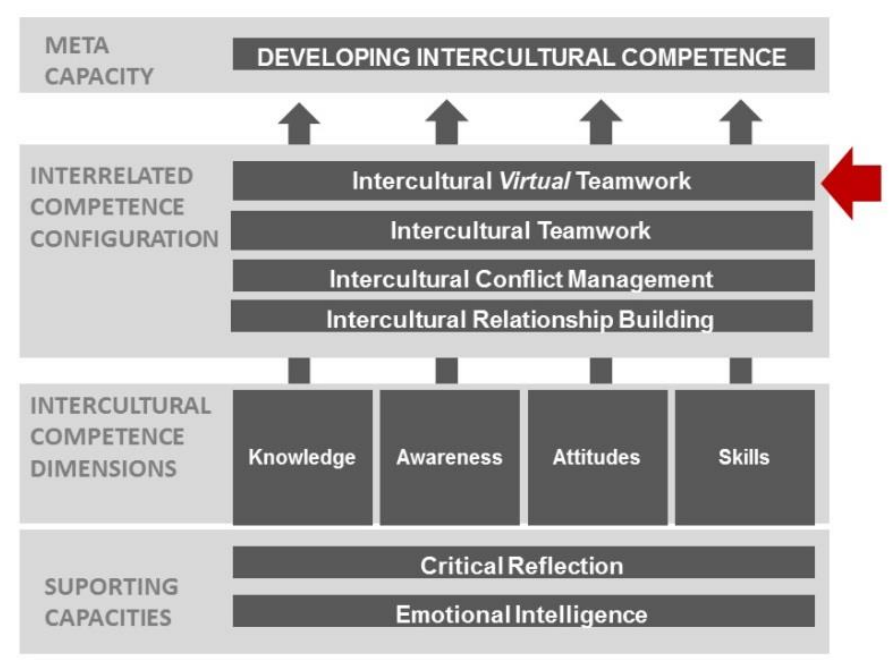

Figure 2. Intercultural Competence Model. Modified from EMIC (2015b, p. 13). Available at: www.emic-project.org/emic-toolkit. Modified with permission

With the addition of a new element to the composition of the model, four corresponding indicators were also included in EMIC's original list of learning outcomes. Such outcomes approach intercultural virtual teamwork from the following different perspectives: knowledge about the main characteristics of virtual work (IVT1), awareness of the impact that technology has on intercultural communication (IVT2), the attitudes needed to carry out virtual teamwork effectively (such as creativity) (IVT3) and finally the ability to carry intercultural virtual teamwork in practice (IVT4).

\begin{tabular}{|l|l|}
\hline IVT1 & $\begin{array}{l}\text { Understand the main characteristic of virtual communication and the role it plays in a } \\
\text { globalized workplace }\end{array}$ \\
\hline IVT2 & $\begin{array}{l}\text { Develop awareness of the impact that virtual communication has on intercultural virtual } \\
\text { teamwork }\end{array}$ \\
\hline IVT3 & $\begin{array}{l}\text { Have a positive attitude in relation to creating strategies to overcome barriers posed by virtual } \\
\text { communication }\end{array}$ \\
\hline IVT4 & $\begin{array}{l}\text { Put strategies to overcome barriers posed by virtual communication into practice when working } \\
\text { in intercultural virtual teams. }\end{array}$ \\
\hline
\end{tabular}

Table 1. Intercultural Virtual Teamwork (IVT) - Learning Outcomes

\section{Tasks Sequence Structure}

As mentioned previsously, the structure of the task sequence proposed herein is based on the typology of tasks found in the work of O'Dowd and Ware (2009). As so, it is composed of an icebreaker, a comparison and analysis of cultural products and two collaborative assignments. We opted to use this sequence because it combines different approaches to achieving varied Intercultural Competence learning outcomes and is 
consonant with what is suggested by other works from the literature (Guth \& Rubin, 2015; Kurek \& Müller-Hartmann, 2017; Müller-Hartmann \& Schocker-von Ditfurth, 2010; Müller-Hartmann, 2006). It also takes into account the importance of fostering relationship building and social presence in telecollaborative teams (Liaw \& English, 2017; Müller-Hartmann, 2000) by going from simpler activities, which present and exchange personal and cultural information, to tasks that are more complex and which require more collaboration. Table 2 offers a detailed description of each task.

As can be observed in Table 2, the task sequence considers the importance of reflection in the process of developing Intercultural Competence (Guth \& Rubin, 2015; MüllerHartmann, 2006) and, after completing each activity, students are asked to reflect about what they have just done. For the icebreaker, the group contract and the final assignment tasks, students receive a link to complete the related reflection tasks in Google forms. The reflection tasks consist of open questions which ask students to reflect on different aspects of the collaboration process (Figure 3). For the Comparison \& Analysis task, the group report handed by students should carry their reflections on the differences and similarities found between group members according to Hofstede's dimensions and therefore can be considered as a reflection task.

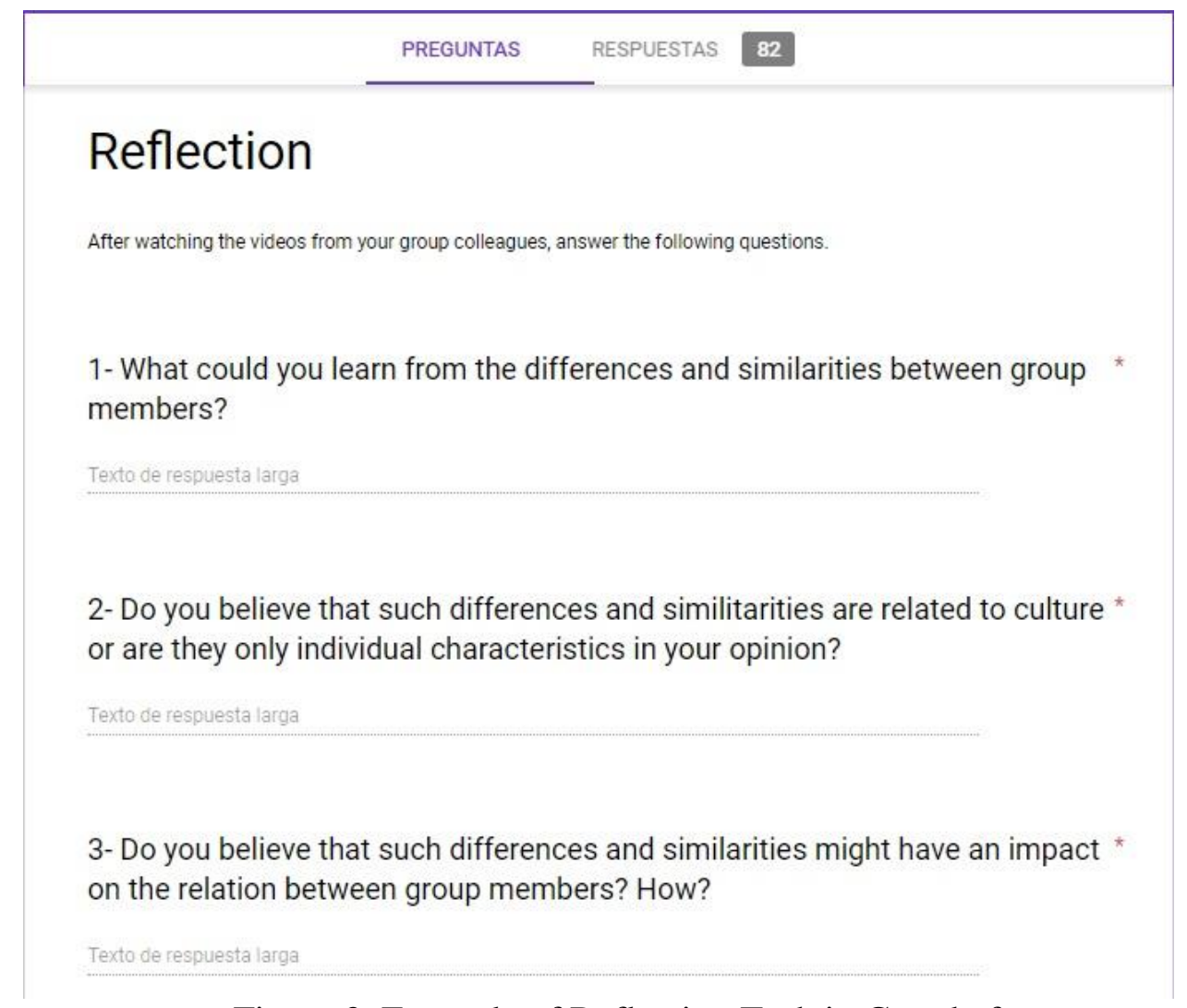

Figure 3. Example of Reflection Task in Google forms 


\begin{tabular}{|c|c|c|c|c|c|c|}
\hline$\underline{\text { Task }}$ & Description & Pedagogical & Learning outcomes & \multicolumn{2}{|c|}{$\underline{\text { Tools }}$} & Estimated \\
\hline $\begin{array}{l}\text { Course } \\
\text { introduction }\end{array}$ & $\begin{array}{l}\text { Presentation of the task sequence (with its objectives and } \\
\text { format) and delivery of other practical information such } \\
\text { as: timeline for the completion of the different tasks, } \\
\text { composition of working groups and instructions on the } \\
\text { technology tools to be used (including on how to access } \\
\text { the online learning platform - e.g. Moodle, Google } \\
\text { Classroom - if any is adopted). } \\
\text { Besides sending the information by e-mail/platform, } \\
\text { teachers should brief students in a face-to-face induction } \\
\text { session to make sure that they learn how to use the } \\
\text { technology tools selected for the exchange. } \\
\text { The teachers can also provide students with video } \\
\text { tutorials about the tools to be used and inform them } \\
\text { about any local technical support services that the } \\
\text { universities involved might offer. }\end{array}$ & $\begin{array}{l}\text { Delivery of } \\
\text { information } \\
\text { Pre-exchange } \\
\text { briefing }\end{array}$ & $\begin{array}{l}\text { Preparation of students } \\
\text { for the programme }\end{array}$ & Instructions: & $\begin{array}{l}\text { E-mail and/or } \\
\text { platform } \\
\text { adopted + face- } \\
\text { to-face } \\
\text { induction } \\
\text { session held by } \\
\text { teachers in each } \\
\text { locality }\end{array}$ & $40-50 \mathrm{~min}$ \\
\hline \multirow[t]{2}{*}{$\begin{array}{l}\text { Pre-tests (self- } \\
\text { evaluation) }\end{array}$} & \multirow{2}{*}{$\begin{array}{l}\text { Students are asked to self-evaluate their level of } \\
\text { Intercultural Competence in relation to the } 48 \text { indicators } \\
\text { defined in the Intercultural Competence model. They are } \\
\text { also asked about their previous international experience } \\
\text { and asked to analyse two intercultural incidents so that } \\
\text { their initial level of Intercultural Competence can be } \\
\text { grasped. }\end{array}$} & \multirow[t]{2}{*}{ Self-evaluation } & \multirow[t]{2}{*}{ All the outcomes listed } & Instructions: & $\begin{array}{l}\text { E-mail and/or } \\
\text { platform } \\
\text { adopted }\end{array}$ & \multirow[t]{2}{*}{$\begin{array}{l}40 \min -1 \\
\text { hour }\end{array}$} \\
\hline & & & & Questionnaire & Google forms & \\
\hline \multirow[t]{2}{*}{ Icebreaker } & \multirow{2}{*}{$\begin{array}{l}\text { Group members are asked to introduce themselves to } \\
\text { each other by posting a video on the shared platform. } \\
\text { Alternatively, if a platform is not adopted, videos can be, } \\
\text { for example, uploaded to Google Drive folders. In the } \\
\text { videos, students should mention points like name, age, } \\
\text { family size, curiosities about their cultures and } \\
\text { expectations towards the virtual collaboration. }\end{array}$} & \multirow{2}{*}{$\begin{array}{l}\text { Exchange of } \\
\text { personal } \\
\text { information for } \\
\text { relationship } \\
\text { building }\end{array}$} & \multirow{2}{*}{$\begin{array}{l}\text { Intercultural } \\
\text { Knowledge (K1), } \\
\text { Intercultural awareness } \\
\text { (AW1, AW2, AW3), } \\
\text { Intercultural } \\
\text { Relationship Building } \\
\text { (IRB2) }\end{array}$} & Instructions: & $\begin{array}{l}\text { E-mail and/or } \\
\text { platform } \\
\text { adopted }\end{array}$ & \multirow[t]{2}{*}{$\begin{array}{l}50 \text { min-1 } \\
\text { hour }\end{array}$} \\
\hline & & & & $\begin{array}{l}\text { Video } \\
\text { recording: }\end{array}$ & $\begin{array}{l}\text { Students can } \\
\text { record their } \\
\text { videos on their } \\
\text { own mobile }\end{array}$ & \\
\hline
\end{tabular}

Integrating Intercultural Competence development into the curriculum through Telecollaboration. A task sequence proposal for Higher Education. Luana Ferreira-Lopes, Maria José Bezanilla and Iciar Elexpuru. 


\begin{tabular}{|c|c|c|c|c|c|c|}
\hline & & & & 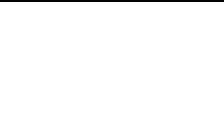 & $\begin{array}{l}\text { devices or } \\
\text { computer } \\
\text { camera }\end{array}$ & \\
\hline & & & & Video sharing: & $\begin{array}{l}\text { Google drive or } \\
\text { platform } \\
\text { adopted }\end{array}$ & \\
\hline \multirow[t]{2}{*}{$\begin{array}{l}\text { Icebreaker - } \\
\text { reflection task }\end{array}$} & \multirow{2}{*}{$\begin{array}{l}\text { Students are asked to answer the following reflection } \\
\text { questions related to the icebreaker task in a Google } \\
\text { forms: } \\
\text { 1. What could you learn from the differences and } \\
\text { similarities between group members? } \\
\text { 2. Do you believe that such differences and similarities } \\
\text { are related to culture or are they only individual } \\
\text { characteristics? } \\
\text { 3- Do you believe that such differences and similarities } \\
\text { might have an impact on the relationship between group } \\
\text { members? How? } \\
4 \text { - How do you relate yourself with your own culture? In } \\
\text { which aspects do you believe that your culture shapes } \\
\text { what you are? } \\
5 . \text { How much did you like this activity? Why? }\end{array}$} & \multirow[t]{2}{*}{ Critical reflection } & \multirow[t]{2}{*}{$\begin{array}{l}\text { Critical Reflection } \\
\text { (CR4, CR5) }\end{array}$} & Instructions: & $\begin{array}{l}\text { E-mail and/or } \\
\text { platform } \\
\text { adopted }\end{array}$ & \multirow[t]{2}{*}{$\begin{array}{l}50 \mathrm{~min}-1 \\
\text { hour }\end{array}$} \\
\hline & & & & Questionnaire: & Google forms & \\
\hline \multirow{3}{*}{$\begin{array}{l}\text { Comparison } \\
\& \text { analysis of } \\
\text { cultural } \\
\text { products }\end{array}$} & \multirow{3}{*}{$\begin{array}{l}\text { In this activity, students are asked to meet online in order } \\
\text { to jointly explore the similarities and differences of the } \\
\text { cultures represented by group members according to the } \\
\text { six National Cultural Dimensions proposed by Geert } \\
\text { Hofstede (individualism x collectivism, power distance, } \\
\text { uncertainty avoidance, femininity x masculinity, restraint } \\
\text { x indulgence, long term x short-term orientation). For } \\
\text { doing so, they should use Geert Hofstede's Country } \\
\text { Comparison Tool (online open source available at } \\
\text { https://www.hofstede-insights.com/country-comparison/) } \\
\text { as basis for discussion. Afterwards, students must } \\
\text { elaborate a report containing:(1) a brief summary of the }\end{array}$} & \multirow{3}{*}{$\begin{array}{l}\text { Comparison and } \\
\text { analysis of } \\
\text { cultural products, } \\
\text { exchange of } \\
\text { cultural } \\
\text { information, } \\
\text { online discussion } \\
\text { and collaborative } \\
\text { group work. }\end{array}$} & \multirow{3}{*}{$\begin{array}{l}\text { Intercultural } \\
\text { Knowledge (K1, K3, } \\
\text { K4), Intercultural } \\
\text { Awareness (AW1, } \\
\text { AW2, AW3), Skills } \\
\text { (S4), Intercutlural } \\
\text { Teamwork (ITM2, } \\
\text { ICM2), Intercultural } \\
\text { Relationship Building } \\
\text { (IRB1, IRB2, IRB4), } \\
\text { Developing } \\
\text { Intercultural }\end{array}$} & Instructions: & $\begin{array}{l}\text { E-mail and/or } \\
\text { platform } \\
\text { adopted }\end{array}$ & \multirow[t]{3}{*}{4 hours } \\
\hline & & & & $\begin{array}{l}\text { Comparison } \\
\text { tool: }\end{array}$ & $\begin{array}{l}\text { Geert } \\
\text { Hofstede's } \\
\text { webpage }\end{array}$ & \\
\hline & & & & $\begin{array}{l}\text { Video } \\
\text { conferencing: }\end{array}$ & $\begin{array}{l}\text { Students can } \\
\text { choose the tool } \\
\text { with which they } \\
\text { feel more } \\
\text { comfortable } \\
\text { with (Skype, }\end{array}$ & \\
\hline
\end{tabular}

Integrating Intercultural Competence development into the curriculum through Telecollaboration. A task sequence proposal for Higher Education. Luana Ferreira-Lopes, Maria José Bezanilla and Iciar Elexpuru. 


\begin{tabular}{|c|c|c|c|c|c|c|}
\hline & $\begin{array}{l}\text { results; (2) reflections on how the different group } \\
\text { members relate or not to the results given for their } \\
\text { respective cultures; (3) an analysis of how differences } \\
\text { and similarities in the countries' results can represent } \\
\text { possible challenges or potentials for the upcoming } \\
\text { groupwork and (4) suggestions of strategies to be used } \\
\text { by the group in order to overcome possible identified } \\
\text { barriers. At least two weeks should be left for the } \\
\text { completion of this activity. }\end{array}$ & & Competence (DIC3 & & $\begin{array}{l}\text { Google } \\
\text { Hangouts, etc) }\end{array}$ & \\
\hline $\begin{array}{l}\text { Comparison } \\
\& \text { analysis - } \\
\text { reflection task }\end{array}$ & $\begin{array}{l}\text { Students are asked to elaborate a group report with the } \\
\text { reflections derived from the group discussion about the } \\
\text { comparison of National Dimensions. }\end{array}$ & Group reflection & $\begin{array}{l}\text { Critical Reflection } \\
\text { (CR3, CR4) and } \\
\text { Developing } \\
\text { Intercultural } \\
\text { Competence (DIC3) }\end{array}$ & $\begin{array}{l}\text { Shared } \\
\text { document: }\end{array}$ & Google docs & 1 hour \\
\hline \multirow[t]{3}{*}{$\begin{array}{l}\text { Elaboration of } \\
\text { group contract }\end{array}$} & \multirow{3}{*}{$\begin{array}{l}\text { Before starting to work on the final assignment,(which is } \\
\text { next in this sequence), as a 'pre-production' task, students } \\
\text { are asked to meet their group colleagues online in order } \\
\text { to discuss their different communication styles and } \\
\text { cultural expectations towards group work. They are also } \\
\text { asked to elaborate a group contract to rule the } \\
\text { collaboration during the development of the last } \\
\text { assignment. Teachers provide the following topics for } \\
\text { discussion (which should appear in the contract): the } \\
\text { frequency of group meetings, tools to be used by the } \\
\text { group in order to compile all the work, expectations } \\
\text { related to the quality of the work to be delivered, } \\
\text { expectations related to the relationship between group } \\
\text { members (dedication, effort, ethics...), the different } \\
\text { communication styles present in the group (e.g. } \\
\text { formal/informal, high context/low context), time } \\
\text { management, strategies to maintain the communication }\end{array}$} & \multirow{3}{*}{$\begin{array}{l}\text { Group discussion } \\
\text { for verbalization } \\
\text { of cultural } \\
\text { expectations, } \\
\text { group reflection } \\
\text { and collaborative } \\
\text { assignment }\end{array}$} & \multirow{3}{*}{$\begin{array}{l}\text { AW2, AW3), } \\
\text { Intercultural Attitude } \\
\text { (AT1, AT3), } \\
\text { Intercultural Skills (S1, } \\
\text { S2, S3, S4, S6), } \\
\text { Intercultural Teamwork } \\
\text { (ITM1, ITM2, ITM3), } \\
\text { Intercultural Conflict } \\
\text { Management (ICM1, } \\
\text { ICM2, ICM 3), } \\
\text { Intercultural } \\
\text { Relationship Building } \\
\text { (IRB1, IRB2, IRB4), } \\
\text { Emotional Intelligence } \\
\text { (EI2, EI3, EI5), } \\
\text { Developing } \\
\text { Intercultural }\end{array}$} & Instructions: & $\begin{array}{l}\text { E-mail and/or } \\
\text { platform } \\
\text { adopted }\end{array}$ & \multirow[t]{3}{*}{1,5 hour } \\
\hline & & & & $\begin{array}{l}\text { Video } \\
\text { conferencing: }\end{array}$ & $\begin{array}{l}\text { Any tool } \\
\text { students feel } \\
\text { more } \\
\text { comfortable } \\
\text { with (Skype, } \\
\text { Google } \\
\text { Hangouts, etc) }\end{array}$ & \\
\hline & & & & $\begin{array}{l}\text { Shared } \\
\text { document: }\end{array}$ & Google docs & \\
\hline
\end{tabular}

Integrating Intercultural Competence development into the curriculum through Telecollaboration. A task sequence proposal for Higher Education. Luana Ferreira-Lopes, Maria José Bezanilla and Iciar Elexpuru. 


\begin{tabular}{|c|c|c|c|c|c|c|}
\hline & $\begin{array}{l}\text { flow in the group and get the work done, strategies to } \\
\text { deal with conflicts that might arise. A template for the } \\
\text { contract can be provided by the teachers (for an } \\
\text { interesting Learning Contract template, see Palomera, } \\
\text { Briones, \& Gómez-Linares (2017)) }\end{array}$ & & $\begin{array}{l}\text { Competence (DIC3), } \\
\text { Intercultural Virtual } \\
\text { Teamwork (IVT1, } \\
\text { IVT2, IVT3) }\end{array}$ & & & \\
\hline $\begin{array}{l}\text { Elaboration of } \\
\text { group contract } \\
\text { - reflection } \\
\text { task }\end{array}$ & $\begin{array}{l}\text {. Students are asked to answer the following reflection } \\
\text { questions related to the task in a Google forms: } \\
\text { 1. How would you define your communication style? } \\
\text { 2- How was it for you to verbalize your (cultural?) } \\
\text { expectations? How did you feel? } \\
\text { 3- Did you need to adjust your expectations or behavior } \\
\text { at any time during the elaboration of the group work } \\
\text { contract so that a common agreement could be met? } \\
\text { 4- Do you believe that technology might impact the } \\
\text { communication in the group? } \\
\text { 5- Do you believe that the cultural differences between } \\
\text { group members might affect the functioning of the group } \\
\text { work? } \\
\text { 6- Did you like this activity? Why? }\end{array}$ & $\begin{array}{l}\text { Group reflection } \\
\text { and collaborative } \\
\text { assignment }\end{array}$ & $\begin{array}{l}\text { Critical Reflection } \\
\text { (CR1, CR2, CR4, } \\
\text { CR5), Developing } \\
\text { Intercultural } \\
\text { Competence (DIC3), }\end{array}$ & $\begin{array}{l}\text { Shared } \\
\text { document }\end{array}$ & Google docs & $40 \mathrm{~min}$ \\
\hline \multirow[t]{2}{*}{$\begin{array}{l}\text { Final } \\
\text { collaborative } \\
\text { assignment }\end{array}$} & \multirow{2}{*}{$\begin{array}{l}\text { For this final task, teachers should elaborate an } \\
\text { assignment related to the participating courses' core } \\
\text { studies. } \\
\text { Such assignment can be designed by teachers in different } \\
\text { formats, depending on the subjects involved. Teachers } \\
\text { from Business, for example, might ask students to } \\
\text { deliver a 5-page joint business case analysis or a } \\
\text { marketing plan. Law teachers might ask students to } \\
\text { deliver a comparison of how the law in the different } \\
\text { countries involved approach a certain issue. } \\
\text { Given its higher complexity, students should be given } \\
\text { more time/weeks to engage in collaboration and } \\
\text { communication with their peers. Besides the learning }\end{array}$} & \multirow[t]{2}{*}{$\begin{array}{l}\text { Group work and } \\
\text { collaborative } \\
\text { assignment }\end{array}$} & \multirow{2}{*}{$\begin{array}{l}\text { All outcomes listed } \\
\text { (except for K2, EI1, } \\
\text { CR3,DIC1, DIC2, } \\
\text { DIC4, DIC5, DIC6 and } \\
\text { IVT1) }\end{array}$} & Instructions: & $\begin{array}{l}\text { E-mail and/or } \\
\text { platform } \\
\text { adopted }\end{array}$ & \multirow[t]{2}{*}{5 hours } \\
\hline & & & & $\begin{array}{l}\text { Communicatio } \\
\mathrm{n} \text { between } \\
\text { students: }\end{array}$ & $\begin{array}{l}\text { Video } \\
\text { conferencing } \\
\text { (Skype, Google } \\
\text { Hangouts, etc), } \\
\text { e-mail } \\
\text { exchange, social } \\
\text { media and/or } \\
\text { platform } \\
\text { adopted }\end{array}$ & \\
\hline
\end{tabular}

Integrating Intercultural Competence development into the curriculum through Telecollaboration. A task sequence proposal for Higher Education. Luana Ferreira-Lopes, Maria José Bezanilla and Iciar Elexpuru. 


\begin{tabular}{|c|c|c|c|c|c|c|}
\hline & $\begin{array}{l}\text { outcomes related to Intercultural Competence, teachers } \\
\text { might decide to use this assignment material for } \\
\text { assessing other objectives related to the content of the } \\
\text { subjects involved. During this phase (last part of the } \\
\text { semester), students will have more autonomy and teacher } \\
\text { should be available to help them to manage conflicts in } \\
\text { case they arise. } \\
\text { An example of instruction for this assignment in a } \\
\text { telecollaboration between two undergraduate business } \\
\text { courses would be: "In this task, you are asked to pick a } \\
\text { company which has business in different countries and } \\
\text { analyse how this company adapts to local cultures. You } \\
\text { can analyse elements like the marketing strategy adopted } \\
\text { by the company in different countries, the kind of } \\
\text { communication that they use in their websites when } \\
\text { translating it to different languages, their hiring policy in } \\
\text { different countries, facilities in different geographic } \\
\text { locations, etc. You can choose classical case studies like } \\
\text { Coca-cola and Ikea or, inversely, you can also propose } \\
\text { an intercultural business strategy to a company that still } \\
\text { does not have one. The report must be } 4.000-5.000 \\
\text { words long and be structured around an introduction, a } \\
\text { theoretical background, the case study presentation, a } \\
\text { critical analysis of the case and a conclusion." }\end{array}$ & & & $\begin{array}{l}\text { Shared } \\
\text { document: }\end{array}$ & Google docs & \\
\hline \multirow[t]{2}{*}{$\begin{array}{l}\text { Collaborative } \\
\text { assignment - } \\
\text { reflection task }\end{array}$} & \multirow{2}{*}{$\begin{array}{l}\text { Students are asked to answer the following reflection } \\
\text { questions sent by the teachers and related to the task in a } \\
\text { Google forms: } \\
1 \text { - During the development of the assignment, did you } \\
\text { notice if, at any moment, participant's cultural } \\
\text { backgrounds were influencing the group work? How did } \\
\text { that happen? } \\
\text { 2- Did you feel judgmental about the behavior that any }\end{array}$} & \multirow[t]{2}{*}{$\begin{array}{l}\text { Individual } \\
\text { reflection }\end{array}$} & \multirow[t]{2}{*}{$\begin{array}{l}\text { Critical Reflection } \\
\text { (CR1, CR2, CR4, CR5) }\end{array}$} & Instructions: & $\begin{array}{l}\text { E-mail and/or } \\
\text { platform } \\
\text { adopted }\end{array}$ & \multirow[t]{2}{*}{$\begin{array}{l}60 \min -90 \\
\min \end{array}$} \\
\hline & & & & Questionnaire: & Google forms & \\
\hline
\end{tabular}

Integrating Intercultural Competence development into the curriculum through Telecollaboration. A task sequence proposal for Higher Education. Luana Ferreira-Lopes, Maria José Bezanilla and Iciar Elexpuru. 


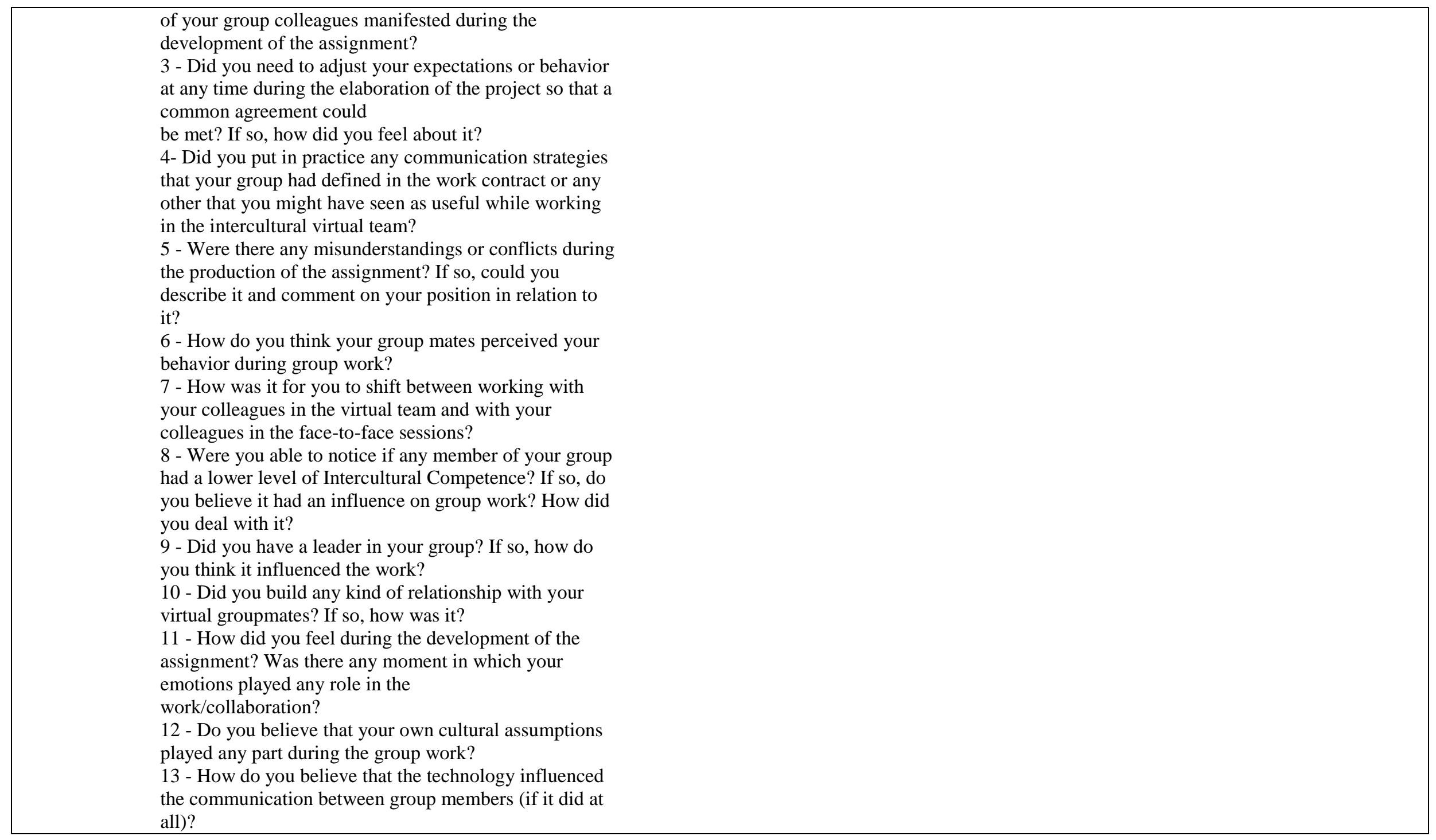

Integrating Intercultural Competence development into the curriculum through Telecollaboration. A task sequence proposal for Higher Education. Luana Ferreira-Lopes, Maria José Bezanilla and Iciar Elexpuru. 
RED. Revista de Educación a Distancia, Núm. 58. Artíc. 7

\begin{tabular}{|c|c|c|c|c|c|c|}
\hline & $\begin{array}{l}14 \text { - Did you need to use any strategy to overcome } \\
\text { barriers posed by technology during the virtual group } \\
\text { work? How was it? }\end{array}$ & & & & & \\
\hline \multirow[t]{2}{*}{ Posttests } & \multirow{2}{*}{$\begin{array}{l}\text { Students are asked to self-evaluate their level of } \\
\text { Intercultural Competence in relation to the } 48 \text { indicators } \\
\text { defined in the Intercultural Competence model (to be } \\
\text { contrasted with results from pre-test). They are also } \\
\text { asked to analyse two intercultural incidents which are } \\
\text { similar to the ones provided in the pre-test. The idea is to } \\
\text { try to identify in students' incident analysis if their } \\
\text { discourse changed/improved somehow after the } \\
\text { collaboration (from pre to posttest). }\end{array}$} & \multirow[t]{2}{*}{ Self-evaluation } & \multirow[t]{2}{*}{ All outcomes listed } & Instructions: & $\begin{array}{l}\text { E-mail and/or } \\
\text { platform } \\
\text { adopted }\end{array}$ & \multirow[t]{2}{*}{$\begin{array}{l}40 \min -1 \\
\text { hour }\end{array}$} \\
\hline & & & & Questionnaire: & Google forms & \\
\hline $\begin{array}{l}\text { Course } \\
\text { conclusion }\end{array}$ & $\begin{array}{l}\text { Wrap-up of the telecollaborative programme. A } \\
\text { satisfaction survey can be applied by teachers to all } \\
\text { students in order to grasp their perceptions towards the } \\
\text { telecollaborative programme. }\end{array}$ & $\begin{array}{l}\text { Delivery of } \\
\text { information } \\
\text { Exchange wrap- } \\
\text { up }\end{array}$ & $\begin{array}{l}\text { Conclusion of the } \\
\text { course, grasp students' } \\
\text { perceptions towards the } \\
\text { programme }\end{array}$ & Instructions: & $\begin{array}{l}\text { E-mail and/or } \\
\text { platform } \\
\text { adopted }\end{array}$ & $30-40 \mathrm{~min}$ \\
\hline
\end{tabular}

Table 2. Task sequence with instructions. 


\section{Integration of online tasks to the coursework}

Since the task sequence aims at being adaptable to the subject into which it will be implemented, it proposes a gradual integration of the tellecolaborative programme into the core subject of the courses. In order to do so, it defines non-specific activities to be held first (Ice-breaker, Comparison and Analysis and Group Contract) to then request a subject-related assignment to be developed in the last task. Ideally, the proposed sequence should be maintained once, as said before, the tasks are ordered in a way to build trust among group members. For better integration to the coursework, it is also suggested that tasks are evenly distributed along the whole course span, following principles of learning process.

We provide in Figure 4 an instance of how the task sequence proposed is currently being implemented in two telecollaborative projects at University of Deusto (UD) in collaboration with two foreign universities. Example 1 consists of a telecollaboration between UD and a French university as part of a joint master course in International Business. Example 2 is a partnership between UD and a Dutch university in an undergraduate Business course.

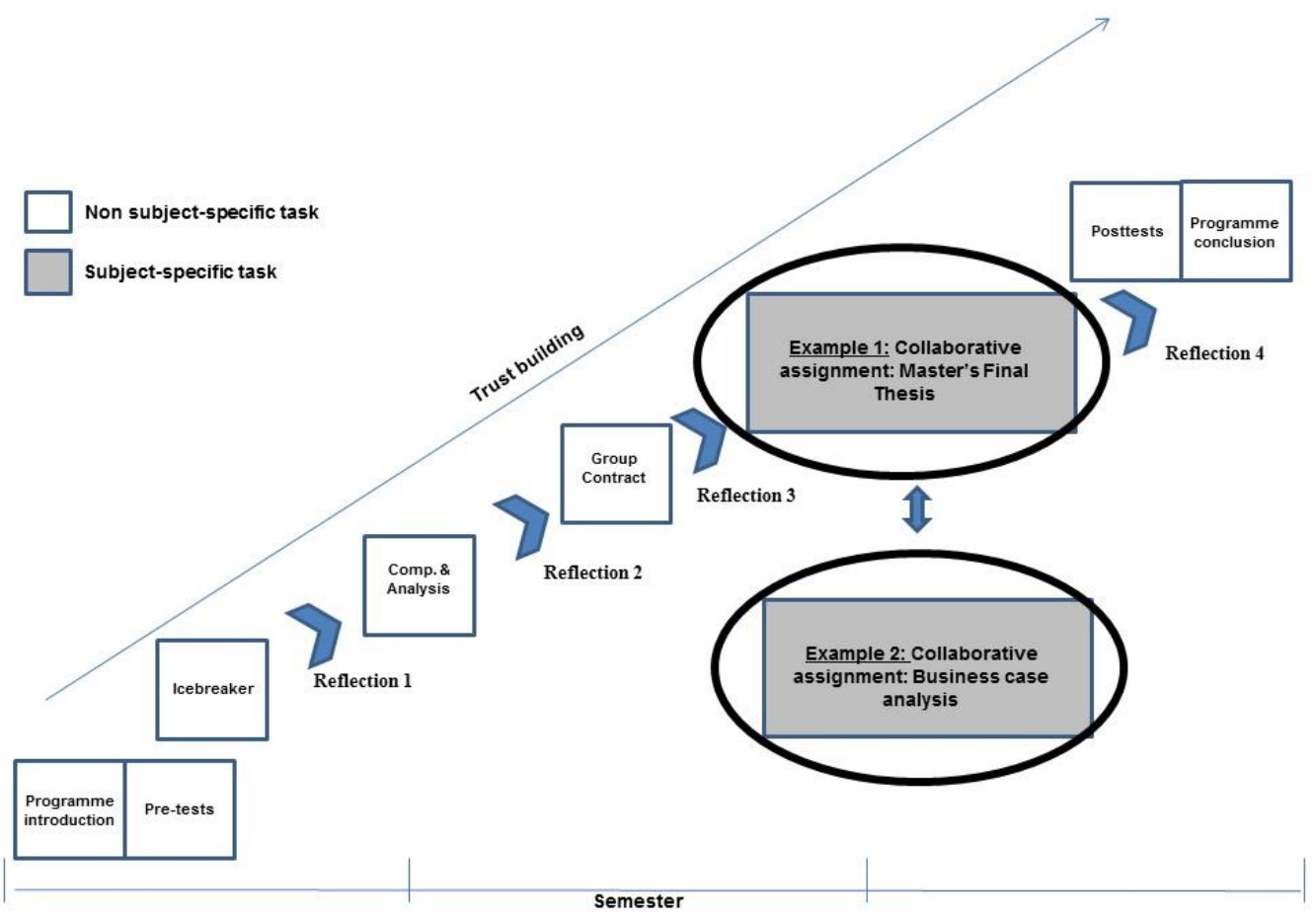

Figure 4. Examples of the integration of the proposed task sequence into course unities (main references: Guth \& Rubin, 2015; Kurek \& Müller-Hartmann, 2017; Lewis \& O' Dowd, 2016b; Müller-Hartmann, 2006; O' Dowd \& Ware, 2009)

As one can see in the examples given, when following the task sequence, teachers from both projects implemented the icebreaker, the comparison and analysis and the elaboration of the group contract without making any changes to the original format proposed, whereas, for the final assignment, students in Example 1 are collaborating in the development of their Final Master's Thesis while students from Example 2 are working in a small business case analysis.

Integrating Intercultural Competence development into the curriculum through Telecollaboration. A task sequence proposal for Higher Education. Luana Ferreira-Lopes, Maria José Bezanilla and Iciar Elexpuru. 


\section{Technology tools}

Given that literature showed that the low level of teachers' e-literacy was one of the greatest barriers to the adoption of telecollaboration as a practice in Higher Education (O'Dowd, 2013a), we suggest what we consider to be basic and well known tools to be used in each task. The choice for Google apps for education (Google Docs, Google Forms, Google Drive) for most of the activities is justified by the increasing adoption of Google by Higher Education institutions (Owayid \& Uden, 2014), by their collaborative and intuitive features (which are useful for the kind of tasks proposed) and by their 'open access', which provide a common ground in which students and teachers from collaborating universities can work together without the need to deal with registration and privacy issues related to specific universities' platforms. Still, teachers can opt to use other tools that they are more comfortable with. In whatever way, we suggest that they adopt the tools that will be of easy use for all parts involved and which will mostly attend the cultural diversity present in groups (Cagiltay et al., 2015).

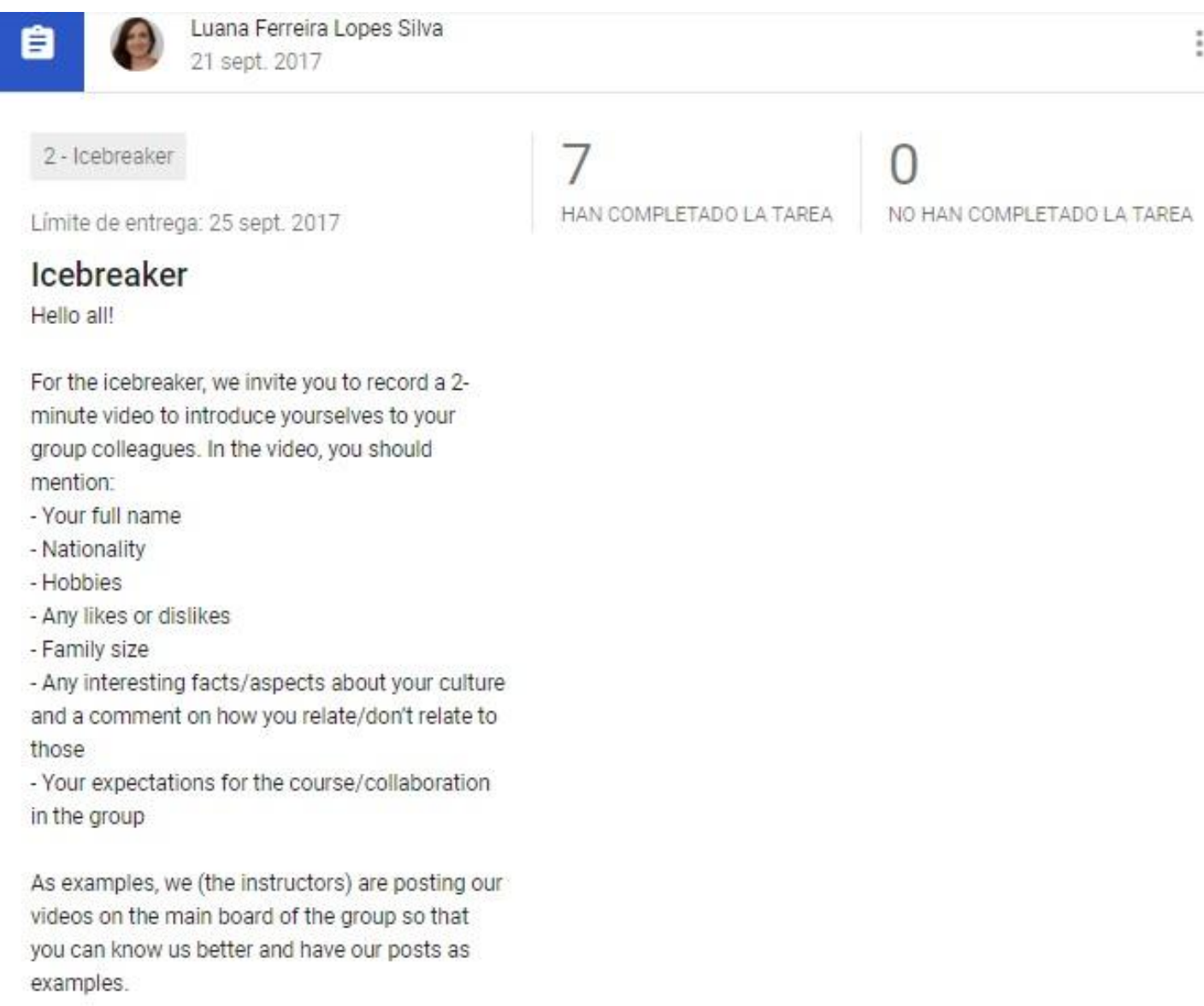

Figure 5. Example of the usage of an online learning platform (Google Classroom) for posting task sequence instructions.

The adoption of a online learning platform (e.g. Google Classroom or Moodle), to which students and teachers from both universities can have access, is strongly recommended, since it can hold all the material related to the course together as well as serve as a platform for intra-group interaction and between students and teachers (see example in Figure 5). In

Integrating Intercultural Competence development into the curriculum through Telecollaboration. A task sequence proposal for Higher Education. Luana Ferreira-Lopes, Maria José Bezanilla and Iciar Elexpuru. 
this case, usability features should be carefully considered and, the more intuitive the use to of the platform is, the less technical problems are likely to arise during collaboration.

\section{Assessment Plan}

In alignment with what literature suggests, the sequence sets forth an ongoing, integrated and multi-method assessment plan to evaluate the development of students' Intercultural Competence during telecollaboration. In order to do so, it suggests that the collection of evaluation material should be placed at different points of the course. Assessment in this material also makes use of different instruments (self-evaluation, videos, reflection tasks, group reports) so to collect different kinds of evaluation material (quantitative and qualitative).

\begin{tabular}{|c|c|c|c|c|}
\hline $\begin{array}{c}\frac{\text { Type of }}{\text { evaluation }} \\
\underline{\text { material }}\end{array}$ & $\frac{\text { Instrument of }}{\text { collection }}$ & Description & $\frac{\text { Collection }}{\text { point }}$ & Suggested tools \\
\hline $\begin{array}{l}\text { Quantitative } \\
+ \text { qualitative }\end{array}$ & $\begin{array}{l}\text { Pre and posttest } \\
\text { self-evaluation } \\
\text { questionnaires }\end{array}$ & $\begin{array}{l}\text { Pre and posttest questionnaires } \\
\text { through which students evaluate } \\
\text { their own level of mastery in } \\
\text { relation to each learning outcome of } \\
\text { the programme (scale from 1-5) } \\
\text { (quantitative evaluation) and also } \\
\text { respond to open questions related to } \\
\text { two intercultural incidents } \\
\text { (qualitative evaluation). }\end{array}$ & $\begin{array}{l}\text { Beginning } \\
\text { and end of } \\
\text { the } \\
\text { programme }\end{array}$ & Google forms \\
\hline Qualitative & Students' videos & $\begin{array}{l}\text { The videos posted by students in the } \\
\text { icebreaker task can be analyzed in } \\
\text { order to assess certain initial } \\
\text { attitudes towards the collaboration } \\
\text { and cultural self-awareness. The } \\
\text { specific evidences expected to be } \\
\text { manifested through this instrument } \\
\text { can be consulted in the appendix }\end{array}$ & Icebreaker & $\begin{array}{l}\text { Videos uploaded } \\
\text { to the online } \\
\text { platform (if any } \\
\text { is adopted) or } \\
\text { shared through a } \\
\text { sharing tool like } \\
\text { Google Drive }\end{array}$ \\
\hline Qualitative & $\begin{array}{l}\text { Reflection } \\
\text { questions }\end{array}$ & $\begin{array}{l}\text { After icebreaker and collaborative } \\
\text { assignments, students receive } \\
\text { questions to answer about the } \\
\text { collaboration with the foreign peers } \\
\text { during the development of the tasks }\end{array}$ & $\begin{array}{l}\text { After } \\
\text { icebreaker, } \\
\text { group } \\
\text { contract and } \\
\text { final } \\
\text { collaborative } \\
\text { assignment }\end{array}$ & Google forms \\
\hline Qualitative & Group reports & $\begin{array}{l}\text { The reflections present in the reports } \\
\text { developed by students as a result of } \\
\text { the Comparison and Analysis task } \\
\text { and also the Group Contract are } \\
\text { considered for evaluation }\end{array}$ & $\begin{array}{l}\text { Comparison } \\
\text { and Analysis } \\
\text { and Group } \\
\text { Contract }\end{array}$ & $\begin{array}{l}\text { Shared } \\
\text { documents } \\
\text { (Google docs) }\end{array}$ \\
\hline
\end{tabular}

Table 3. Intercultural Competence Assessment Plan

Since literature shows that telecollaborative activities should be seen as assessable and credit-bearing tasks $\left(\mathrm{O}^{\prime}\right.$ Dowd, 2013), it is suggested that the work derived from the online

Integrating Intercultural Competence development into the curriculum through Telecollaboration. A task sequence proposal for Higher Education. Luana Ferreira-Lopes, Maria José Bezanilla and Iciar Elexpuru. 
exchange corresponds to at least $15 \%$ of students' grading in the courses in which it is being implemented.

In order to operationalize EMIC's learning outcomes for the assessment of students' contributions, we have also specified in a table (appendix) the evidences which are expected to be manifested/delivered by students per instrument in each if of the tasks proposed. The idea is to provide teachers with a concrete instrument to assess how each task of the sequence contributed to develop students' Intercultural Competence.

Finally, the results from pre-post tests can be contrasted with the evidences manifested by students through the application of the qualitative instruments. This way, a more holistic diagnostic of students' Intercultural Competence development during their participation in the proposed sequence can be obtained.

\section{Conclusion}

This paper aims to make a contribution to the development of Intercultural Competence through telecollaboration. As shown by the previous works analysed, there is a need for instructional design models for the development of interculturality (Zapata, 2014) and for implementing and evaluating sustainable formats of telecollaboration to allow more students and educators to engage in this practice with important implications for the internationalisation of Higher Education (Helm, 2015).

To this end, a task sequence is proposed to support Higher Education teachers in the design and implementation of telecollaborative programmes for the development of Intercultural Competence. Based on the typology of tasks from O'Dowd \& Ware (2009) and on other important works from the field of intstructional design in telecollaboration, the task sequence is composed of an icebreaker, a comparison and analysis of cultural products and two collaborative assignments. The material contained in this work not only suggests the adoption of the EMIC model as a theoretical reference for the definition and development of Intercultural Competence in the context given, but also adds a new block and four related learning outcomes to its original composition in order to approach the specificities of virtual teamwork. The sequence also offers concrete and detailed instructions for the tasks proposed including the time estimated for completing each of them. Furthermore, guidelines on the implementation of tasks and on the selection of technologies are given as well a a multiperspective and multi-method assessment plan. Another contribution from this work is the elaboration of a table which lists the specific evidences that are expected to be manifested by students in each of the tasks proposed and that can serve as a practical instrument for the assessment of students' Intercultural Competence with reference to EMIC model.

The proposed sequence aims at being interdisciplinary and customizable. Although only the theoretical background is presented in this article, it is being currently implemented in two telecollaboration projects at University of Deusto in collaboration with other foreign universities. By doing so, we expect to be able to evaluate the effectiveness of the learning programme proposed by the guide in developing students' Intercultural Competence through telecollaboration and intend to grasp students perceptions towards the different aspects of the programme. The lessons learned from such implementations will offer suggestions of improvements for future applications of the guide in different Higher Education contexts.

Integrating Intercultural Competence development into the curriculum through Telecollaboration. A task sequence proposal for Higher Education. Luana Ferreira-Lopes, Maria José Bezanilla and Iciar Elexpuru.

Página 23 de 36 
We expect that this proposal will be of interest for the integration of Intercultural Competence development into Higher Education by means of tellecolaboration.

Article submitted: April 29, 2018 Article accepted: September 15, 2018

Article published: October 31, 2018

Ferreira-Lopes, L., Bezanilla, M. J. \& Elexpuru, I. (2018). Integrating Intercultural Competence Development into the Curriculum through Telecollaboration. A Task Sequence Proposal for Higher Education. RED. Revista de Educación a Distancia, 58. Consultado el (dd/mm/aaaa) en http://www.um.es/ead/red/58

\section{Funding}

This research was financially supported by The Research Training Grants Programme of University of Deusto (2015-2018).

\section{References}

Ang, S., Dyne, L. Van, Koh, C., Ng, K. Y., Templer, K. J., Tay, C., \& Chandrasekar, N. A. (2007). Cultural Intelligence: Its Measurement and Effects on Cultural Judgment and Decision Making, Cultural Adaptation and Task Performance. Management and Organization Review, 3(3), 335-371.

Arasaratnan-Smith, L. A. (2017). Intercultural Competence. An overview. In D. K. Deardorff \& L. A. Arasaratnan-Smith (Eds.), Intercultural Competence in Higher Education. International Approaches, Assessment and Application (pp. 7-17). New York: Routledge.

Bennett, M. J. (1993). Towards Ethnorelativism: A Developmental Model of Intercultural Sensitivity. Intercultural Press.

Byram, M. (1997). Teaching and assessing intercultural communicative competence. Multilingual Matters.

Cagiltay, K., Bichelmeyer, B., Kaplan Akilli, G., Berge, Z., Berry, G., Bichelmeyer, B., ... Alavi, M. (2015). Working with multicultural virtual teams: critical factors for facilitation, satisfaction and success. Smart Learning Environments, 2(1), 11. https://doi.org/10.1186/s40561-015-0018-7

Calloway-Thomas, Arasaratnan-Smith, L. A., \& Deardorff, D. K. (2017). The Role of Empathy in Fostering Intercultural Competence. In D. K. Deardorff \& L. A. Arasaratnan-Smith (Eds.), Intercultural Competence in Higher Education. International Approaches, Assessment and Application (pp. 32-42). New York: Routledge.

Çiftçi, E. Y. (2016). A Review of Research on Intercultural Learning through ComputerBased Digital Technologies. Educational Technology \& Society, 19(2), 313-327.

Deardorff, D. K. (2006). Assessing intercultural competence in study abroad students. Languages for Intercultural Communication and Education, 12, 232.

Integrating Intercultural Competence development into the curriculum through Telecollaboration. A task sequence proposal for Higher Education. Luana Ferreira-Lopes, Maria José Bezanilla and Iciar Elexpuru. 
EMIC. (2015). EMIC Theoretical Approach. Retrieved from http://www.emicproject.org/wp-content/uploads/2014/03/Theoretical-Approach_Summary-table.pdf

EMIC. (2015). EMIC Toolkit. Retrieved from http://www.emic-project.org/wpcontent/uploads/2015/10/EMIC-toolkit.pdf

EMIC. (2015). Evaluation Report: Erasmus Mundus Intercultural Competence. Retrieved from http://www.emic-project.org/wp-content/uploads/2014/03/EMIC-EvaluationReport.pdf

European University Association. (2016). Retrieved December 20, 2016, from http://www.eua.be/activities-services/events/event/2016/04/07/default-calendar/euaannual-conference-2016

Fantini, A. (2009). Assessing Intercultural Competence: Issues and Tools. In The SAGE Handbook of Intercultural Competence (pp. 456-476). Inc.: USA.: SAGE Publications.

Fantini, A. E. (2005). About Intercultural Communicative Competence: A Construct. Retrieved from http://federationeil.org/documents/AppendixE.pdf

Fuchs, C. (2006). Computer-mediated negotiation across borders: German-American collaboration in language teacher education. Frankfurt am Main: Peter Lang.

Fuchs, C., Hauck, M., \& Müller-Hartmann, A. (2012). Promoting learner autonomy through multiliteracy skills development in cross-institutional exchanges. Language Learning \& Technology, 16(3), 82-102.

Guerin, E. M. C., Cigognini, M. E., \& Pettenati, M. C. (2010). Learner 2.0. In Telecollaboration 2.0: Language, Literacies and Intercultural Learning in the 21st Century (pp. 199-218). Peter Lang.

Guth, S., Helm, F., \& O’Dowd, R. (2012). University Language Classes Collaborationg Online - Report on the Integration of Telecollaborative Networks in European Universities. Retrieved from http://www.unicollaboration.org/wpcontent/uploads/2016/06/1.1-Telecollaboration_report_Executive_summaryOct2012_0.pdf

Guth, S., \& Rubin, J. (2015). Collaborative Online International Learning: An Emerging Format for Internationalizing Curricula. In Globally Networked Learning in the Humanities (pp. 16-27).

Guth, S., \& Thomas, M. (2010). Telecollaboration with Web 2.0 Tools. In S. Guth \& F. Helm (Eds.), Telecollaboration 2.0: Language, Literacies and Intercultural Learning in the 21st Century (pp. 39-68). Peter Lang.

Hauck, M. (2010). The Enactment of Task Design in Telecollaboration 2.0. In Task-based language learning and teaching with technology (pp. 197-217).

Helm, F. (2015). The Practices and Challenges of Telecollaboration in Higher Education in Europe. Language Learning \& Technology, 19(2), 197-217.

King, P., \& Baxter Magolda, M. (2005). A Developmental Model of Intercultural Maturity ProQuest. Journal of College Student Development, 46(6), 571-592. Retrieved from https://search-proquest-com.proxy-

oceano.deusto.es/docview/195183723?OpenUrlRefId=info:xri/sid:primo\&accountid=1 4529

Kramsch, C., \& Thorne, S. (2002). Foreign language learning as global communicative practice. Globalization and Language Teaching, 83-100.

Kurek, M., \& Müller-Hartmann, A. (2017). Task design for telecollaborative exchanges: In search of new criteria. https://doi.org/10.1016/j.system.2016.12.004

Lai, C., \& Li, G. (2011). Technology and Task- Based Language Teaching: A Critical Review. CALICO Journal Technology -Based CALICO Journal Journal, 28(2).

Integrating Intercultural Competence development into the curriculum through Telecollaboration. A task sequence proposal for Higher Education. Luana Ferreira-Lopes, Maria José Bezanilla and Iciar Elexpuru. 
Retrieved from https://search-proquest-com.proxyoceano.deusto.es/docview/896164089?rfr_id=info\%3Axri\%2Fsid\%3Aprimo

Lee, L. (2011). Blogging: Promoting Learner Autonomy and Intercultural Competence through Study Abroad. Language Learning \& Technology, 15(3), 87-109.

Lewis, T., \& O'Dowd, R. (2016a). Online Intercultural Exchange and Foreign Language Learning: A Systematic Review. In Online Intercultural Exchange: Policy, Pedagogy, Practice (pp. 21-68).

Lewis, T., \& O'Dowd, R. (2016b). Online Intercultural Exchange and Foreign Language Learning: A Systematic Review. In R. O’Dowd \& T. Lewis (Eds.), Online Intercultural Exchange: Policy, Pedagogy, Practice (pp. 21-66). Routledge.

Liaw, M.-L. (2006). E-learning and the Development of Intercultural Competence. Language Learning \& Technology, 10(3), 49-64. Retrieved from http://llt.msu.edu/vol10num3/liaw/

Liaw, M.-L., \& English, K. (2017). Identity and addressivity in the "Beyond These Walls" program. https://doi.org/10.1016/j.system.2016.12.005

Lukic, D., Solari, M., Martins, H., \& Yarosh, M. (2017). Erasmus Mundus Intercultural Competence - Results and EMIC Toolkit. In Proceedings of EDULEARN Conference. Barcelona: IATED.

Lukic, D., Solari, M., \& Yarosh, M. (n.d.). Developing Intercultural Competence in Erasmus Mundus: Reflective Practice Through Technology-enhanced learning. Retrieved from http://www.emic-project.org/wp-content/uploads/2014/03/DevelopingIntercultural-Competence-in-Erasmus-Mundus-Reflective-practice-through-technoloyenhanced-learning.pdf

Müller-Hartmann, A. (2000). The Role of Tasks in Promoting Intercultural Learning in Electronic Learning Networks. Language Learning \& Technology, 4(2), 117-135. Retrieved from http://llt.msu.edu/vol4num2/muller/default.html

Müller-Hartmann, A. (2006). Learning How to Teach Intercultural Communicative Competence via Telecollaboration: A Model for Language Teacher Education. In Internet-mediated intercultural foreign language education (pp. 63-84). Retrieved from

http://citeseerx.ist.psu.edu/viewdoc/download?doi=10.1.1.535.3471\&rep=rep1\&type=p $\mathrm{df}$

Müller-Hartmann, A., \& Schocker-von Ditfurth, M. (2010). Research on the Use of Technology in Task-based Language Teaching. In M. Thomas \& H. Reinders (Eds.), Task-based language learning and teaching with technology (pp. 17-40). London: Continuum.

Nissen, E. (2016). Combining Classroom-Based Learning and Online Intercultural Exchange in Blended Learning Courses. Online Intercultural Exchange: Policy, Pedagogy, 173-191.

O'Dowd, R. (2007). Evaluating the outcomes of online intercultural exchange. ELT Journal, 61(2).

O'Dowd, R. (2010). Issues in the assessment of online interaction and exchange. Telecollaboration 2.0, 337-360.

O'Dowd, R. (2013). Telecollaborative Networks in University Higher Education: Overcoming Barriers to Integration. The Internet and Higher Education, (18), 47-53.

O'Dowd, R. (2016). Learning from the Past and Looking to the Future of Online Intercultural Exchange. In R. O'Dowd \& T. Lewis (Eds.), Online Intercultural Exchange: Policy, Pedagogy, (pp. 273-293). New York: Taylor \& Francis.

Integrating Intercultural Competence development into the curriculum through Telecollaboration. A task sequence proposal for Higher Education. Luana Ferreira-Lopes, Maria José Bezanilla and Iciar Elexpuru.

Página 26 de 36 
O’Dowd, R., \& Lewis, T. (2016). Introduction to Online Intercultural Exchange and This Volume. In Online Intercultural Exchange: Policy, Pedagogy, Practice (pp. 3-20).

O'Dowd, R., \& Ritter, M. (2006). Understanding and working with "failed communication" in telecollaborative exchanges. CALICO Journal, 23(3), 623-642.

O'Dowd, R., \& Ware, P. (2009). Critical issues in telecollaborative task design. Computer Assisted Language Learning, 22(2), 173-188.

Owayid, A. M., \& Uden, L. (2014). The Usage of Google Apps Services in Higher Education (pp. 95-104). Springer, Cham. https://doi.org/10.1007/978-3-319-10671-7_9

Palomera, R., Briones, E., \& Gómez-Linares, A. (2017). Martín, R. P., Pérez, E. B., \& Linares, A. G. (2017). Diseño, desarrollo y resultados de un programa de educación socio-emocional para la formación de docentes a nivel de grado y postgrado. Contextos Educativos, 20, 165-182.

Raffaghelli, J. E., \& Richieri, C. (2012). A classroom with a view: networked learning strategies to promote intercultural education. In Exploring the theory, pedagogy and practice of networked learning (pp. 99-119). New York: Springer.

Sadler, R., \& Dooly, M. (2016). Twelve years of telecollaboration: what we have learnt. ELT Journal, 70(4), 401-413. https://doi.org/10.1093/elt/ccw041

Schenker, T. (2012). Intercultural Competence and Cultural Learning through Telecollaboration. CALICO Journal, 29(3), 449-470.

Schuetze, U. (2008). Exchanging Second Language Messages Online: Developing an Intercultural Communicative Competence? Foreign Language Annals, 41(4), 660-673. https://doi.org/10.1111/j.1944-9720.2008.tb03323.x

Spitzberg, B., \& Changnon, G. (2009). Conceptualizing intercultural competence. In SAGE handbook of intercultural competence (pp. 2-52).

Taras, V., Caprar, D. V., Rottig, D., Sarala, R. M., Zakaria, N., Zhao, F., ... Huang, V. Z. (2013). A Global Classroom? Evaluating the Effectiveness of Global Virtual Collaboration as a Teaching Tool in Management Education. Academy of Management Learning \& Education, 12(3), 414-435. https://doi.org/10.5465/amle.2012.0195

Taras, V., Caprar, D. V., Rottig, D., Sarala, R. M., Zakaria, N., Zhao, F., ... Huang, V. Z. (2013). A global classroom evaluating the effectiveness of global virtual collaboration as a teaching tool in management education. Academy of Management Learning and Education, 12(3), 414-435. https://doi.org/10.5465/amle.2012.0195

Teresevičienė, T., Volungevičienè, A., \& Daukšienė, E. (2011). Virtual Mobility for Teachers and Students in Higher Education. Comparative research study on virtual mobility. Kaunas.

Vallés, E. (2017). Percepción del Alumnado con Respecto al Desarrollo de la Competencia Intercultural en el Proyecto Telecolaborativo ETwinning "Preparados para un Erasmus!Prets pour un Erasmus! Tendencias Pedagógicas, 30, 245-266.

Vinagre, M. (2014). El desarrollo de la competencia intercultural en los intercambios telecolaborativos The Development of Intercultural Competence in Telecollaborative Exchanges. RED. Revista de Educación a Distancia, 41(15). Retrieved from http://www.um.es/ead/red/41

Vinagre, M. (2017). Developing teachers' telecollaborative competences in online experiential learning. https://doi.org/10.1016/j.system.2016.12.002

Vogt, K. (2006). Can you measure attitudinal factors in intercultural communication? Tracing the development of attitudes in e-mail projects. ReCALL, 18(2), 153. https://doi.org/10.1017/S095834400600022X

Ware, P. D., \& Kramsch, C. (2005). Toward an Intercultural Stance: Teaching German and

Integrating Intercultural Competence development into the curriculum through Telecollaboration. A task sequence proposal for Higher Education. Luana Ferreira-Lopes, Maria José Bezanilla and Iciar Elexpuru. 
English through Telecollaboration. The Modern Language Journal, 89, 190-205. https://doi.org/10.1111/j.1540-4781.2005.00274.x

Wu, W.-C. V., Marek, M., \& Chen, N.-S. (2013). Assessing cultural awareness and linguistic competency of EFL learners in a CMC-based active learning context. System, 41(3), 515-528. https://doi.org/10.1016/J.SYSTEM.2013.05.004

Yang, Y.-F. (2013). Exploring Students' Language Awareness through Intercultural Communication in Computer-supported Collaborative Learning. Educational Technology \& Society, 16(2), 325-342. Retrieved from https://search-proquestcom.proxyoceano.deusto.es/docview/1355669550?rfr_id=info\%3Axri\%2Fsid\%3Aprimo

Zapata-Ros, M. (2014). Hacia una nueva interculturalidad (educativa). RED. Revista de Educación a Distancia, 41 . 


\section{Appendix}

EMIC Learning Outcomes + Intercultural Virtual Teamwork with Respective Expected Evidences per Task

\begin{tabular}{|c|c|c|c|c|c|c|}
\hline \multirow{2}{*}{\multicolumn{2}{|c|}{$\begin{array}{c}\text { EMIC Intercultural } \\
\text { Competence Dimensions + } \\
\text { Intercultural Virtual } \\
\text { Teamwork }\end{array}$}} & \multirow{3}{*}{ 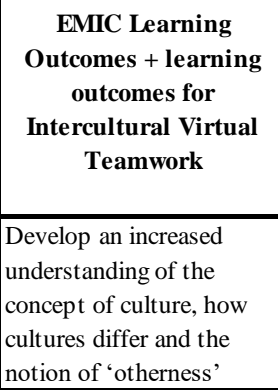 } & \multicolumn{4}{|c|}{ Expected evidences per task } \\
\hline & & & Icebreaker & Comparison \& Analysis & Group contract & Final assignment \\
\hline \multirow{4}{*}{ Knowledge } & K1 & & $\begin{array}{l}\text { RT - After watching the videos from } \\
\text { his/her peers, the student points out } \\
\text { specific cultural aspects learned from } \\
\text { other colleagues' cultures }\end{array}$ & $\begin{array}{c}\text { Report - The report explains how the } \\
\text { different cultures present in the group } \\
\text { differ according to the six dimensions } \\
\text { of Hofstede's model }\end{array}$ & $\begin{array}{c}\text { RT - Student mentions specific aspects } \\
\text { of the individual cultures represented in } \\
\text { the group that he/she learned during the } \\
\text { elaboration of the contract }\end{array}$ & $\begin{array}{l}\text { RT - Student mentions specific aspects of } \\
\text { the individual cultures represented in the } \\
\text { group that he/she learned during the } \\
\text { development of the assignment }\end{array}$ \\
\hline & K2 & $\begin{array}{l}\text { Gain knowledge of the } \\
\text { main concepts related to } \\
\text { Intercultural Competence }\end{array}$ & N.A. & N.A. & N.A. & N.A. \\
\hline & K3 & $\begin{array}{l}\text { Identify vocabulary and } \\
\text { concepts that are required } \\
\text { in intercultural situations }\end{array}$ & N.A. & $\begin{array}{c}\text { Report - The comparison of cultures } \\
\text { presented uses specific and } \\
\text { appropriate vocabulary according to } \\
\text { Hofstede's theory (e.g. collectivism x } \\
\text { individualism, uncertainty avoidance, } \\
\text { etc.) }\end{array}$ & $\begin{array}{l}\text { Contract - The contract approaches key } \\
\text { concepts according to which cultures } \\
\text { may differ (like time management, } \\
\text { expectations, work style, Hofstede's } \\
\text { National Dimensions and communication } \\
\text { style) }\end{array}$ & $\begin{array}{c}\text { RT - When reporting about the process of } \\
\text { collaboration, the student uses appropriate } \\
\text { vocabulary and approaches key concepts } \\
\text { according to which cultures may differ (like } \\
\text { time management, expectations, work style, } \\
\text { Hofstede's National Dimensions and } \\
\text { communication style) }\end{array}$ \\
\hline & K4 & $\begin{array}{l}\text { Develop an understanding } \\
\text { of the relationship } \\
\text { between culture-specific } \\
\text { knowledge and } \\
\text { stereotypes }\end{array}$ & N.A. & $\begin{array}{l}\text { Report - The contract expresses } \\
\text { understanding that Hofstede's } \\
\text { dimensions are general cultural } \\
\text { descriptions and that individual's } \\
\text { behaviors are influenced by many } \\
\text { forces other than those }\end{array}$ & $\begin{array}{c}\text { RT - Student explicitly reflects on the } \\
\text { relationship between stereotypes that } \\
\text { he/she had before the collaboration and } \\
\text { the behavior from colleagues in practice } \\
\text { during the group work }\end{array}$ & $\begin{array}{c}\text { RT - Student explicitly reflects on the } \\
\text { relationship between stereotypes that } \\
\text { he/she had before the collaboration and the } \\
\text { behavior from colleagues in practice during } \\
\text { the group work }\end{array}$ \\
\hline
\end{tabular}

Integrating Intercultural Competence development into the curriculum through Telecollaboration. A task sequence proposal for Higher Education. Luana Ferreira-Lopes, Maria José Bezanilla and Iciar Elexpuru. 
RED. Revista de Educación a Distancia, Núm. 58. Artíc. 7

\begin{tabular}{|c|c|c|c|c|c|c|}
\hline \multirow[t]{3}{*}{ Awareness } & AW1 & $\begin{array}{l}\text { Develop intercultural awareness - } \\
\text { awareness of differences between } \\
\text { cultures }\end{array}$ & $\begin{array}{l}\text { RT - Student points out cultural } \\
\text { differences and similarities } \\
\text { between group members }\end{array}$ & $\begin{array}{c}\text { Report - The differences and } \\
\text { similarities of the cultures represented } \\
\text { in the group according to all the six of } \\
\text { Hofstede's National Cultural } \\
\text { Dimensions are highlighted }\end{array}$ & $\begin{array}{c}\text { Contract - The contract clearly indicates } \\
\text { cultural differences and/or similarities } \\
\text { between group members in terms of time } \\
\text { management, expectations, work style, } \\
\text { Hofstede's National Dimensions and } \\
\text { communication style } \\
\text { RT - Student mentions differences and } \\
\text { similarities between group members } \\
\text { which he/she noticed during the } \\
\text { elaboration of the contract }\end{array}$ & $\begin{array}{l}\mathrm{RT}-\text { Student mentions differences and } \\
\text { similarities between group members which } \\
\text { he/she noticed during the development of } \\
\text { the assignment }\end{array}$ \\
\hline & AW2 & $\begin{array}{l}\text { Increase cultural self-awareness - } \\
\text { awareness of oneself as a cultural } \\
\text { being and of the fact that our own } \\
\text { behavior, views and reactions are } \\
\text { conditioned by our own cultures }\end{array}$ & $\begin{array}{l}\text { Video - Student provides } \\
\text { information about his/her own culture }\end{array}$ & \begin{tabular}{|c|} 
Report - The report contains \\
reflections on how different groups \\
members relate or not to their own \\
cultures' scores and characteristics in \\
relation to the six of Hofstede's \\
National Cultural Dimensions \\
\end{tabular} & $\begin{array}{c}\text { RT }- \text { Student indicates how his/her own } \\
\text { culture influences his/her work style }\end{array} \mid$ & $\begin{array}{c}\text { RT - Student explains if and/or how his/her } \\
\text { own cultural assumptions influenced the } \\
\text { group work during the development of the } \\
\text { assignment }\end{array}$ \\
\hline & AW3 & $\begin{array}{l}\text { Increase awareness of specific } \\
\text { cases when cultural conditioning is } \\
\text { at play - not only knowing that } \\
\text { culture is supposed to influence } \\
\text { human behaviors but being capable } \\
\text { of identifying this influence in } \\
\text { practice }\end{array}$ & $\begin{array}{l}\text { RT - Student reflects on how the } \\
\text { behavior/information that group } \\
\text { colleagues deliver in the videos might be } \\
\text { influenced by their respective cultures. } \\
\text { An example of this type would be: "I } \\
\text { could see that all students from the other } \\
\text { group demonstrated to be very open } \\
\text { towards the collaboration whereas } \\
\text { students from our group were more } \\
\text { serious and this might be connected to } \\
\text { their cultural background" }\end{array}$ & $\begin{array}{l}\text { Report - The report contains real } \\
\text { examples of how the different } \\
\text { dimensions from Hofstede's theory are } \\
\text { expressed in practice in the different } \\
\text { cultures represented in the group. } \\
\text { Statements from this type might be }\end{array}$ & $\begin{array}{c}\text { RT - Student reports to have noticed } \\
\text { cultural forces playing a role during the } \\
\text { elaboration of the contract and describes } \\
\text { how it happened }\end{array}$ & $\begin{array}{l}\text { RT - Student reports to have noticed } \\
\text { cultural forces play ing a role during the } \\
\text { elaboration of the contract and describes } \\
\text { how it happened }\end{array}$ \\
\hline Attitudes & AT1 & $\begin{array}{l}\text { Become aware of attitudes needed } \\
\text { for higher levels of Intercultural } \\
\text { Competence (such as acceptance of } \\
\text { differences, openness, non- } \\
\text { judgmental attitude, tolerance, a } \\
\text { cooperative mindset, flexibility, } \\
\text { valuing diversity and respect for } \\
\text { culturally-different others) }\end{array}$ & N.A. & N.A. & $\begin{array}{c}\text { Contract - Attitudes needed to ensure a } \\
\text { good intercultural interaction between } \\
\text { group members, such as openness, } \\
\text { empathy and respect, are mentioned in } \\
\text { the contract } \\
\text { RT - Student exp licitly reflects on the } \\
\text { attitudes needed to ensure a good } \\
\text { intercultural interaction between group } \\
\text { members, such as openness, empathy } \\
\text { and respect in his/her answers }\end{array}$ & $\begin{array}{l}\text { RT - Student mentions how him/herself or } \\
\text { other members of the group having or } \\
\text { lacking certain attitudes needed to ensure a } \\
\text { good level of Intercultural Competence } \\
\text { affected the group work }\end{array}$ \\
\hline
\end{tabular}

Integrating Intercultural Competence development into the curriculum through Telecollaboration. A task sequence proposal for Higher Education. Luana Ferreira-Lopes, Maria José Bezanilla and Iciar Elexpuru. 
RED. Revista de Educación a Distancia, Núm. 58. Artíc. 7

\begin{tabular}{|c|c|c|c|c|c|c|}
\hline & AT2 & $\begin{array}{l}\text { Practice ap plying non-judgmental } \\
\text { attitudes - not judging culturally- } \\
\text { different behavior and non- } \\
\text { judgmental attitudes in general }\end{array}$ & N.A. & N.A. & $\begin{array}{c}\text { RT - Student reports examples of } \\
\text { him/herself or group members applying } \\
\text { non-judgmental attitudes during the } \\
\text { collaboration } \\
\text { RT - Student reports cases when } \\
\text { judgmental attitudes affected the group } \\
\text { work }\end{array}$ & $\begin{array}{c}\text { RT - Student reports examples of } \\
\text { him/herself or group members applying non- } \\
\text { judgmental attitudes during the collaboration } \\
\text { RT - Student reports cases when judgmental } \\
\text { attitudes affected the group work }\end{array}$ \\
\hline & АT3 & $\begin{array}{l}\text { Develop openness to adjust } \\
\text { behavior in intercultural } \\
\text { interactions }\end{array}$ & N.A. & N.A. & $\begin{array}{c}\text { Contract - Openness to adjust behavior } \\
\text { as is explicitly mentioned in the contract } \\
\text { as one of the keys/strategies to a } \\
\text { successful intercultural interaction in the } \\
\text { group }\end{array}$ & $\begin{array}{c}\text { RT - Student reports if he/she had to adjust } \\
\text { behavior at any time during the elaboration } \\
\text { of the project so that a common agreement } \\
\text { could be met }\end{array}$ \\
\hline \multirow[t]{4}{*}{ Skills } & S1 & $\begin{array}{l}\text { Develop practical intercultural } \\
\text { communication approaches }\end{array}$ & N.A. & N.A. & \begin{tabular}{|} 
Contract - The contract proposes \\
practical communication approaches to \\
be taken by the group in order to ensure \\
a good communication flow \\
RT - Student reports practical \\
intercultural communication approaches \\
adopted by the group during the \\
elaboration of the contract
\end{tabular} & $\begin{array}{c}\text { RT - Student mentions practical } \\
\text { communication that were adopted by the } \\
\text { group in order to ensure a good } \\
\text { communication flow during the develop ment } \\
\text { of the assignment }\end{array}$ \\
\hline & S2 & $\begin{array}{l}\text { Develop an ability to mediate in an } \\
\text { intercultural situation }\end{array}$ & N.A. & N.A. & $\begin{array}{l}\text { RT - Student reports if he/she had to } \\
\text { mediate the collaboration at any point } \\
\text { and how he/she did it }\end{array}$ & $\begin{array}{l}\text { RT - Student reports if he/she had to } \\
\text { mediate the collaboration at any point and } \\
\text { how he/she did it }\end{array}$ \\
\hline & S3 & $\begin{array}{l}\text { Practice verbalizing cultural } \\
\text { expectations and norms, discussing } \\
\text { expectations and speaking about } \\
\text { culturally different practices that } \\
\text { are disturbing, ability to speak } \\
\text { about cultural differences }\end{array}$ & N.A. & N.A. & $\begin{array}{l}\text { RT - Student reports how it was for } \\
\text { him/her to verbalize his/her cultural } \\
\text { expectations during the elaboration of } \\
\text { the contract }\end{array}$ & $\begin{array}{c}\text { RT - Student reports how it was for } \\
\text { him/her to verbalize his/her cultural } \\
\text { expectations during the development of the } \\
\text { assignment }\end{array}$ \\
\hline & S4 & $\begin{array}{l}\text { Identify the impact of cultural } \\
\text { differences in misunderstandings }\end{array}$ & N.A. & $\begin{array}{l}\text { Report - the report contains } \\
\text { reflections of how differences and } \\
\text { similarities between the countries' } \\
\text { results might cause misunderstandings } \\
\text { between group members }\end{array}$ & $\begin{array}{c}\text { Contract - The contract identifies } \\
\text { specific aspects in which cultural } \\
\text { differences present in the group might } \\
\text { cause misunderstandings (for example, in } \\
\text { time management or expectations in } \\
\text { terms of quality of work) } \\
\text { RT - Student reports if cultural } \\
\text { differences created misunderstandings at } \\
\text { any point during the elaboration }\end{array}$ & $\begin{array}{l}\text { RT - Student reports if cultural differences } \\
\text { created misunderstandings at any point } \\
\text { during the elaboration of the contract }\end{array}$ \\
\hline
\end{tabular}

Integrating Intercultural Competence development into the curriculum through Telecollaboration. A task sequence proposal for Higher Education. Luana Ferreira-Lopes, Maria José Bezanilla and Iciar Elexpuru. 
RED. Revista de Educación a Distancia, Núm. 58. Artíc. 7

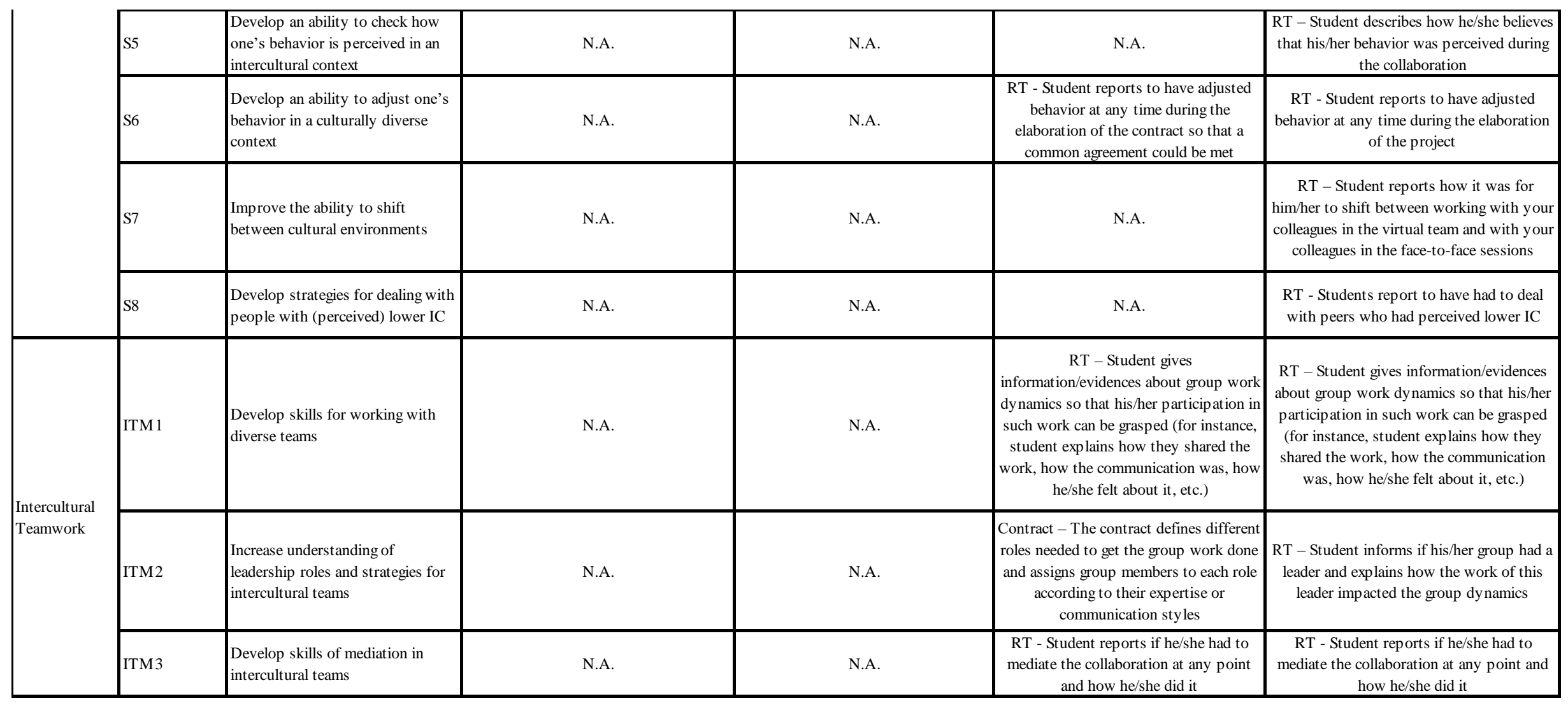

Integrating Intercultural Competence development into the curriculum through Telecollaboration. A task sequence proposal for Higher Education. Luana Ferreira-Lopes, Maria José Bezanilla and Iciar Elexpuru. 


\begin{tabular}{|c|c|c|c|c|c|c|}
\hline \multirow[t]{3}{*}{$\begin{array}{l}\text { Intercultural } \\
\text { Conflict } \\
\text { Management }\end{array}$} & ICM 1 & $\begin{array}{l}\text { Understand the impact of } \\
\text { Intercultural Competence on } \\
\text { conflicts }\end{array}$ & N.A. & N.A. & \begin{tabular}{|} 
Contract - The contract identifies \\
specific aspects in which cultural \\
differences present in the group might \\
cause conflicts \\
RT - Student reports if cultural \\
differences created conflicts at any point \\
during the elaboration of the contract
\end{tabular} & $\begin{array}{l}\text { RT - Student reports if cultural differences } \\
\text { created conflicts at any point during the } \\
\text { elaboration of the contract }\end{array}$ \\
\hline & ICM2 & $\begin{array}{l}\text { Be aware of strategies for } \\
\text { identifying, analyzing and solving } \\
\text { intercultural conflicts }\end{array}$ & N.A. & N.A. & $\begin{array}{l}\text { Contract }- \text { The contract identifies } \\
\text { specific strategies for addressing } \\
\text { conflicts that might arise from cultural } \\
\text { differences present in the group } \\
\end{array}$ & $\begin{array}{l}\text { RT - Student reports strategies used by the } \\
\text { group to overcome conflicts that might have } \\
\text { derived from the cultural differences existing } \\
\text { in the group }\end{array}$ \\
\hline & ICM3 & $\begin{array}{l}\text { Develop skills for effectively } \\
\text { dealing with conflicts related to } \\
\text { cultural differences }\end{array}$ & N.A. & N.A. & $\begin{array}{c}\text { RT }- \text { Students report if any conflict } \\
\text { arose during the elaboration of the } \\
\text { contract and explains how he/she or the } \\
\text { group dealt with it }\end{array}$ & $\begin{array}{c}\text { RT - Student reports if any conflict arose } \\
\text { during the development of the assignment } \\
\text { and explains how he/she or the group dealt } \\
\text { with it }\end{array}$ \\
\hline \multirow[t]{2}{*}{$\begin{array}{l}\text { Intercultural } \\
\text { Relationship } \\
\text { Building }\end{array}$} & |IRB1 & $\begin{array}{l}\text { Increase awareness of issues and } \\
\text { challenges in intercultural } \\
\text { relationship building }\end{array}$ & N.A. & $\begin{array}{c}\text { Report - The report presents potential } \\
\text { challenges that the intercultural } \\
\text { differences in the group might impose } \\
\text { to the upcoming teamwork }\end{array}$ & \begin{tabular}{|}
$\begin{array}{c}\text { Contract }- \text { The contract lists potential } \\
\text { challenges that the cultural differences } \\
\text { present in the group might impose to the } \\
\text { creation of relationship between group } \\
\text { members } \\
\text { RT - Student explicitly reflects on the } \\
\text { potential challenges that the cultural } \\
\text { differences present in the group might } \\
\text { impose to the creation of relationship } \\
\text { between group members }\end{array}$ \\
\end{tabular} & $\begin{array}{c}\text { RT - Student reports on relationship } \\
\text { challenges and issues derived from cultural } \\
\text { differences that might have arouse during the } \\
\text { collaboration }\end{array}$ \\
\hline & IRB2 & $\begin{array}{l}\text { Develop a positive attitude to } \\
\text { intercultural relationships }\end{array}$ & $\begin{array}{l}\text { RT - Student shows a positive attitude } \\
\text { towards building relationship with group } \\
\text { members from other culture }\end{array}$ & $\begin{array}{c}\text { Report - A positive attitude towards } \\
\text { the intercultural relationship building } \\
\text { between group members is exp ressed } \\
\text { in the report with statements like } \\
\text { "despite of our cultural differences, we } \\
\text { believe that we can develop good } \\
\text { relationship" }\end{array}$ & $\begin{array}{c}\text { RT }- \text { Student expresses a positive } \\
\text { attitude towards the intercultural } \\
\text { relationship building between group } \\
\text { members with statements like "I am } \\
\text { very excited to work in this group" or } \\
\text { "we are working really well together", } \\
\text { etc. }\end{array}$ & $\begin{array}{l}\text { RT - Student expresses a positive attitude } \\
\text { towards the intercultural relationship } \\
\text { building between group members in the } \\
\text { aftermath of the telecollaboration with } \\
\text { statements like "working with the } \\
\text { international peers was a very nice } \\
\text { experience and I am looking forward to } \\
\text { having this kind of experience again" }\end{array}$ \\
\hline
\end{tabular}

Integrating Intercultural Competence development into the curriculum through Telecollaboration. A task sequence proposal for Higher Education. Luana Ferreira-Lopes, Maria José Bezanilla and Iciar Elexpuru. 


\begin{tabular}{|c|c|c|c|c|c|c|}
\hline & IRB3 & $\begin{array}{l}\text { Develop ability to form, develop } \\
\text { and maintain intercultural } \\
\text { relationships (private or work) }\end{array}$ & N.A. & N.A. & \begin{tabular}{|c|} 
RT - Student provides evidence that \\
group members are building relationship \\
with statements like "we started the \\
conversation talking about the \\
assignment, but in the end we were \\
talking about our personal lives. I think \\
we will be more than groupmates and \\
might become friends"
\end{tabular} & $\begin{array}{l}\text { RT - Student provides evidence that group } \\
\text { members built relationship with statements } \\
\text { like "the work was really nice, we talked } \\
\text { about many things and created a good work } \\
\text { atmosphere" }\end{array}$ \\
\hline & IRB4 & $\begin{array}{l}\text { Develop strategies for encouraging } \\
\text { intercultural relationships in one's } \\
\text { environment (private or work) }\end{array}$ & N.A. & $\begin{array}{l}\text { Report - Strategies for encouraging } \\
\text { intercultural relationships between } \\
\text { group members are highlighted }\end{array}$ & $\begin{array}{c}\text { Report - Strategies for encouraging } \\
\text { intercultural relationships between group } \\
\text { members are cited in the contract }\end{array}$ & $\begin{array}{c}\text { RT - Student reports to have used strategie } \\
\text { to encourage intercultural relationships } \\
\text { between group members }\end{array}$ \\
\hline \multirow[t]{5}{*}{$\begin{array}{l}\text { Emotional } \\
\text { Intelligence }\end{array}$} & E1 & $\begin{array}{l}\text { Gain knowledge about the concept } \\
\text { of emotional intelligence and its use }\end{array}$ & N.A. & N.A. & N.A. & N.A. \\
\hline & E2 & $\begin{array}{l}\text { Develop awareness of one's own } \\
\text { emotions }\end{array}$ & N.A. & N.A. & $\begin{array}{l}\text { RT - Student reports how he/she felt } \\
\text { when verbalizing his/her cultural } \\
\text { expectations during the elaboration of } \\
\text { the contract }\end{array}$ & $\begin{array}{l}\text { RT - Student reports how he/she felt during } \\
\text { the development of the assignment }\end{array}$ \\
\hline & E3 & $\begin{array}{l}\text { Increase one's ability to manage } \\
\text { own emotions }\end{array}$ & N.A. & N.A. & $\begin{array}{c}\text { RT - Student reports to have needed to } \\
\text { manage his/her own emotions when } \\
\text { verbalizing his/her cultural expectations } \\
\text { and coming to agreements for the } \\
\text { contract }\end{array}$ & $\begin{array}{c}\text { RT - Student reports that to have needed to } \\
\text { manage his/her own emotions when } \\
\text { interacting with students from different } \\
\text { cultural backgrounds during the } \\
\text { collaboration } \\
\end{array}$ \\
\hline & E4 & $\begin{array}{l}\text { Improve one's ability to notice and } \\
\text { understand emotional perspectives } \\
\text { of culturally different others } \\
\text { through empathy }\end{array}$ & N.A. & N.A. & $\begin{array}{c}\text { RT - Student explicitly reflects on how } \\
\text { colleagues from other cultural } \\
\text { backgrounds expressed (or not) emotions } \\
\text { during the elaboration of the contract }\end{array}$ & $\begin{array}{l}\text { RT - Student explicitly reflects on how } \\
\text { colleagues from other cultural backgrounds } \\
\text { expressed (or not) emotions during the } \\
\text { elaboration of the contract }\end{array}$ \\
\hline & E5 & $\begin{array}{l}\text { Develop an ability to deal with } \\
\text { emotions in teamwork and conflict } \\
\text { situation }\end{array}$ & N.A. & N.A. & $\begin{array}{c}\text { RT - Student reports to have needed to } \\
\text { manage with their own or others' } \\
\text { emotions during the elaboration of the } \\
\text { contract }\end{array}$ & $\begin{array}{l}\text { RT - Student reports to have needed to } \\
\text { manage with their own or others' emotions } \\
\text { during the elaboration of the contract }\end{array}$ \\
\hline
\end{tabular}

Integrating Intercultural Competence development into the curriculum through Telecollaboration. A task sequence proposal for Higher Education. Luana Ferreira-Lopes, Maria José Bezanilla and Iciar Elexpuru. 
RED. Revista de Educación a Distancia, Núm. 58. Artíc. 7

\begin{tabular}{|c|c|c|c|c|c|c|}
\hline \multirow[t]{5}{*}{$\begin{array}{l}\text { Critical } \\
\text { Reflection }\end{array}$} & CR1 & $\begin{array}{l}\text { Develop the capacity to deal with } \\
\text { stereotypes (they have themselves } \\
\text { or others might have about their } \\
\text { culture) }\end{array}$ & N.A. & N.A. & $\begin{array}{c}\text { RT - Student explicitly reflects on the } \\
\text { relationship between stereotypes that } \\
\text { he/she had before the collaboration and } \\
\text { the behavior from colleagues in practice } \\
\text { during the group work }\end{array}$ & $\begin{array}{c}\text { RT - Student explicitly reflects on the } \\
\text { relationship between stereotypes that } \\
\text { he/she had before the collaboration and the } \\
\text { behavior from colleagues in practice during } \\
\text { the group work }\end{array}$ \\
\hline & CR2 & $\begin{array}{l}\text { Develop cognitive flexibility and/or } \\
\text { ability to analyze intercultural } \\
\text { encounters through a culturally- } \\
\text { aware perspective and seeing } \\
\text { things from different cultural } \\
\text { perspectives }\end{array}$ & N.A. & N.A. & $\begin{array}{c}\text { RT - Student gives concrete examples of } \\
\text { situations when different cultural } \\
\text { backgrounds influenced the group work } \\
\text { during the elaboration of the contract, } \\
\text { "telling the story" from different } \\
\text { perspectives } \\
\end{array}$ & $\begin{array}{c}\text { RT - Student gives concrete examples of } \\
\text { situations when different cultural } \\
\text { backgrounds influenced the group work } \\
\text { during the development of the assignment, } \\
\text { "telling the story" from different } \\
\text { perspectives } \\
\end{array}$ \\
\hline & CR3 & $\begin{array}{l}\text { Develop a critical approach to } \\
\text { culture-specific knowledge }\end{array}$ & N.A. & $\begin{array}{c}\text { Report - The report "holds a } \\
\text { discussion" with Hofstede's theory, } \\
\text { highlighting how members relate or not } \\
\text { to results and not only reporting the } \\
\text { scores in an automatic way } \\
\end{array}$ & N.A. & N.A. \\
\hline & CR4 & $\begin{array}{l}\text { Increase critical awareness of one's } \\
\text { own assumptions and behavior in } \\
\text { an intercultural context }\end{array}$ & $\begin{array}{l}\text { RT - Student explicitly reflects on how } \\
\text { his/her behavior is influenced by his/her } \\
\text { own culture }\end{array}$ & $\begin{array}{c}\text { Report - Reflections on how each } \\
\text { member relates or not to the score } \\
\text { results for their respective cultures are } \\
\text { presented }\end{array}$ & $\begin{array}{c}\text { RT - Student reflects on how culture } \\
\text { influences his/her own communication } \\
\text { style }\end{array}$ & $\begin{array}{l}\text { RT - Student explicitly reflects on how } \\
\text { he/she believes that his/her own culture } \\
\text { influenced his behavior during the group } \\
\text { work }\end{array}$ \\
\hline & CR5 & $\begin{array}{l}\text { Increase critical awareness of } \\
\text { others' behaviors in an intercultural } \\
\text { context }\end{array}$ & $\begin{array}{l}\text { RT - Student identifies characteristics of } \\
\text { group colleagues which are linked to their } \\
\text { respective cultural backgrounds and not } \\
\text { only take them as simple individual } \\
\text { manifestations }\end{array}$ & N.A. & $\begin{array}{l}\text { RT - Student reports to have noticed } \\
\text { patterns in the behavior or } \\
\text { characteristics from collaborating peers } \\
\text { that are influenced by culture (e.g. "I } \\
\text { could notice that students from the other } \\
\text { university are in general more direct and } \\
\text { organized...") }\end{array}$ & $\begin{array}{l}\text { RT - Student reports to have noticed } \\
\text { patterns in the behavior or characteristics } \\
\text { from collaborating peers that are influenced } \\
\text { by culture (e.g. "I could notice that students } \\
\text { from the other university are in general more } \\
\text { direct and organized...") }\end{array}$ \\
\hline \multirow[t]{2}{*}{\begin{tabular}{|l|} 
Developing \\
Intercultural \\
Competence
\end{tabular}} & DIC1 & $\begin{array}{l}\text { Demonstrate understanding of } \\
\text { learning strategies for developing } \\
\text { Intercultural Competence }\end{array}$ & N.A. & N.A. & N.A. & N.A. \\
\hline & DIC2 & $\begin{array}{l}\text { Increase understanding of one's } \\
\text { own learning and development } \\
\text { approach to IC development }\end{array}$ & N.A. & N.A. & N.A. & N.A. \\
\hline
\end{tabular}

Integrating Intercultural Competence development into the curriculum through Telecollaboration. A task sequence proposal for Higher Education. Luana Ferreira-Lopes, Maria José Bezanilla and Iciar Elexpuru. 
RED. Revista de Educación a Distancia, Núm. 58. Artíc. 7

\begin{tabular}{|c|c|c|c|c|c|c|}
\hline & DIC3 & $\begin{array}{l}\text { Know how to identify logistic, } \\
\text { specific and in-depth knowledge of } \\
\text { individual cultures }\end{array}$ & N.A. & $\begin{array}{l}\text { Report - Report presents logistic, } \\
\text { specific and in-depth knowledge of } \\
\text { individual cultures represent in the } \\
\text { group in relation to Hofstede's six } \\
\text { dimensions }\end{array}$ & $\begin{array}{c}\text { RT - Student mentions specific and in- } \\
\text { depth aspects of the individual cultures } \\
\text { represented in the group that he/she } \\
\text { learned during the elaboration of the } \\
\text { contract } \\
\end{array}$ & $\begin{array}{c}\text { RT - Student mentions specific and in-depth } \\
\text { aspects of the individual cultures } \\
\text { represented in the group that he/she learned } \\
\text { during the development of the final } \\
\text { assignment }\end{array}$ \\
\hline & DIC4 & $\begin{array}{l}\text { Develop an attitude of lifelong- } \\
\text { learning in relation to Intercultural } \\
\text { Competence development }\end{array}$ & N.A. & N.A. & N.A. & N.A. \\
\hline & DIC5 & $\begin{array}{l}\text { Develop awareness of one's own } \\
\text { level of Intercultural Competence } \\
\text { in order to identify developmental } \\
\text { needs }\end{array}$ & N.A. & N.A. & N.A. & N.A. \\
\hline & DIC6 & $\begin{array}{l}\text { Develop an ability to set } \\
\text { objectives, plan actions and reflect } \\
\text { on owns progress in Intercultural } \\
\text { Competence development }\end{array}$ & N.A. & N.A. & N.A. & N.A. \\
\hline $\begin{array}{l}\text { Intercultural } \\
\text { Virtual } \\
\text { Teamwork }\end{array}$ & IVT 1 & $\begin{array}{l}\text { Understand the main } \\
\text { characteristics of virtual } \\
\text { communication and the role it } \\
\text { plays in a globalized workplace } \\
\text { nowadays }\end{array}$ & N.A. & N.A. & N.A. & N.A. \\
\hline & IVT2 & $\begin{array}{l}\text { Develop awareness of the impact } \\
\text { that virtual communication has on } \\
\text { intercultural virtual teamwork }\end{array}$ & N.A. & N.A. & $\begin{array}{c}\text { RT - Student explicitly reflects on the } \\
\text { impact that technology might have on } \\
\text { the intercultural group work }\end{array}$ & $\begin{array}{l}\text { RT - Student describes how technology } \\
\text { impacted the group work during the } \\
\text { development of the assignment }\end{array}$ \\
\hline & IVT3 & $\begin{array}{l}\text { Have a positive attitude in relation } \\
\text { to creating strategies to overcome } \\
\text { barriers posed by virtual } \\
\text { communication }\end{array}$ & N.A. & N.A. & $\begin{array}{l}\text { RT - Student expresses a positive } \\
\text { attitude towards working with peers } \\
\text { from the other cultures through } \\
\text { technology. Statements of this type } \\
\text { would be: "although working from a } \\
\text { distance might not be easy, if we follow } \\
\text { the strategies defined in the contract, I } \\
\text { believe we will be able to work well } \\
\text { together" } \\
\end{array}$ & $\begin{array}{c}\text { RT - Student expresses satisfaction with the } \\
\text { strategies adopted by the group to overcome } \\
\text { the barriers posed by technology }\end{array}$ \\
\hline & IVT4 & $\begin{array}{l}\text { Put strategies to overcome barriers } \\
\text { posed by virtual communication } \\
\text { into practice when working in } \\
\text { intercultural virtual teams }\end{array}$ & N.A. & N.A. & $\begin{array}{l}\text { RT - Student reports the strategies used } \\
\text { by the group in order to deal with } \\
\text { technology during collaboration }\end{array}$ & $\begin{array}{c}\text { RT - Student reports the strategies used by } \\
\text { the group in order to deal with technology } \\
\text { during collaboration }\end{array}$ \\
\hline
\end{tabular}

Legend: N.A. = Not Applicable; RT = Reflection Task

Modified from EMIC (2015). Available at: www.emic-project.org/emic-toolkit. Modified with permission

Integrating Intercultural Competence development into the curriculum through Telecollaboration. A task sequence proposal for Higher Education. Luana Ferreira-Lopes, Maria José Bezanilla and Iciar Elexpuru. 